\title{
Dynamic and flexible H3K9me3 bridging via HP1 dimerization establishes a plastic state of condensed chromatin
}

Kyoko Hiragami-Hamada ${ }^{1, \star}$, Szabolcs Soeroes ${ }^{1, *, \dagger}$, Miroslav Nikolov $^{1,2}$, Bryan Wilkins $^{3}$, Sarah Kreuz ${ }^{1}$, Carol Chen ${ }^{4}$, Inti A. De La Rosa-Velázquez ${ }^{5}$, Hans Michael Zenn ${ }^{6}$, Nils Kost ${ }^{1}$, Wiebke Pohl ${ }^{7}$, Aleksandar Chernev ${ }^{2,8}$, Dirk Schwarzer ${ }^{9}$, Thomas Jenuwein ${ }^{5}$, Matthew Lorincz ${ }^{4}$, Bastian Zimmermann ${ }^{6}$, Peter Jomo Walla 7,10 , Heinz Neumann ${ }^{3}$, Tuncay Baubec ${ }^{11}$, Henning Urlaub ${ }^{2,8} \&$ Wolfgang Fischle ${ }^{1}$

Histone $\mathrm{H} 3$ trimethylation of lysine 9 ( $\mathrm{H} 3 \mathrm{~K} 9 \mathrm{me} 3$ ) and proteins of the heterochromatin protein 1 (HP1) family are hallmarks of heterochromatin, a state of compacted DNA essential for genome stability and long-term transcriptional silencing. The mechanisms by which H3K9me3 and HP1 contribute to chromatin condensation have been speculative and controversial. Here we demonstrate that human HP1 is a prototypic HP1 protein exemplifying most basal chromatin binding and effects. These are caused by dimeric and dynamic interaction with highly enriched $\mathrm{H} 3 \mathrm{~K} 9 \mathrm{me} 3$ and are modulated by various electrostatic interfaces. HP1 $\beta$ bridges condensed chromatin, which we postulate stabilizes the compacted state. In agreement, HP1 $\beta$ genome-wide localization follows H3K9me3enrichment and artificial bridging of chromatin fibres is sufficient for maintaining cellular heterochromatic conformation. Overall, our findings define a fundamental mechanism for chromatin higher order structural changes caused by HP1 proteins, which might contribute to the plastic nature of condensed chromatin.

\footnotetext{
${ }^{1}$ Laboratory of Chromatin Biochemistry, Max Planck Institute for Biophysical Chemistry, Göttingen, Am Fassberg 11, 37077, Germany. ${ }^{2}$ Bioanalytical Mass Spectrometry, Max Planck Institute for Biophysical Chemistry, Göttingen, Am Fassberg 11, 37077, Germany. ${ }^{3}$ Applied Synthetic Biology, Institute for Microbiology and Genetics, Georg-August University Göttingen, 37077 Göttingen, Germany. ${ }^{4}$ Department of Medical Genetics, Life Sciences Institute, The University of British Columbia, Vancouver, British Columbia, Canada V6T 1Z3. ${ }^{5}$ Department of Epigenetics, Max Planck Institute of Immunobiology and Epigenetics, Stübeweg 51, 79108 Freiburg, Germany. ${ }^{6}$ Biaffin GmbH \& Co KG, Heinrich-Plett Strasse 40, 34132 Kassel, Germany. ${ }^{7}$ Biomolecular Spectroscopy and Single-Molecule Detection, Max Planck Institute for Biophysical Chemistry, Göttingen, Am Fassberg 11, 37077, Germany. ${ }^{8}$ Bioanalytics, Institute for Clinical Chemistry, University Medical Center Göttingen, Robert-Koch-Strasse 40, 37075 Göttingen, Germany. ${ }^{9}$ Interfaculty Institute of Biochemistry, University of Tübingen, Hoppe-Seyler-Str. 4, 72076 Tübingen, Germany. ${ }^{10}$ Department of Biophysical Chemistry, Technische Universität Braunschweig, Hans-Sommerstr. 10, 38106 Braunschweig, Germany. ${ }^{11}$ Department of Molecular Mechanisms of Disease, University of Zürich, Winterthurerstrasse 190, 8057 Zürich, Switzerland. * These authors contributed equally to this work. $\dagger$ Present address: Oxford Nanopore Technologies LTD, Oxford, UK. Correspondence and requests for materials should be addressed to W.F. (email: wfischl@mpibpc.mpg.de).
} 
H eterochromatin is important for genome stability and transcriptional silencing through folding of chromatin into a condensed higher order structure. Methylation of lysine 9 within the histone $\mathrm{H} 3 \mathrm{~N}$-terminal tail is a crucial determinant of heterochromatin formation. The trimethylated form of this modification (H3K9me3) can be found at pericentric heterochromatin in virtually all higher eukaryotes and is viewed as a hallmark of transcriptionally silenced chromatin ${ }^{1,2}$.

Multiple evidence from genetic and cell biology studies points to an important involvement of heterochromatin protein 1 (HP1) factors, a family of non-histone chromatin proteins found in different isoforms in diverse organisms from $S$. pombe (Swi6) to human (HP1 $\alpha, \beta$ and $\gamma$ ) in establishing and maintaining heterochromatic states ${ }^{2-6}$.

HP1 proteins generally contain two conserved globular domains, a chromo domain (CD) and a chromoshadow domain (CSD), which are linked by a less conserved, flexible hinge region $(\mathrm{HR})^{3}$. Depending on the species and isoforms, additional less-conserved regions are found at the $\mathrm{N}$ and $\mathrm{C}$ termini of the proteins (NT and CT, respectively; Fig. 1a). The CD mediates interaction with $\mathrm{H} 3 \mathrm{~K} 9 \mathrm{me} 3$ histone tail peptides with relatively low (micromolar) affinity ${ }^{7,8}$. Work on isolated chromatin components (peptides, histones, DNA) has suggested that the $\mathrm{CD} / \mathrm{H} 3 \mathrm{~K} 9 \mathrm{me} 3$ interaction might not be sufficient for chromatin targeting of HP1 proteins. Contacts via the HR or CSD might also be required. The issue is further complicated by self-dimerization of the CSD, which provides an interaction platform for a plethora of other proteins ${ }^{9,10}$. Several recent studies on human HP1 $\alpha$ $(\mathrm{hHP} 1 \alpha)$ using in vitro reconstituted 'designer chromatin' containing defined histone modifications have reported conflicting results regarding binding specificity, chromatin effects as well as dependency on different domains of the protein $^{11-14}$.

Here we investigated the molecular parameters and consequences of interaction between hHP1 $\beta$ and H3K9me3containing oligonucleosomes. We focused on this isoform as it is the only essential mammalian HP1 protein, whose knockout in mice leads to perinatal lethality and severe genomic instability ${ }^{15}$ Our results demonstrate that mammalian HP1 $\beta$ is a prototypic $\mathrm{HP} 1$ protein, whose specific interaction with $\mathrm{H} 3 \mathrm{~K} 9 \mathrm{me} 3$ chromatin only requires dimerization and spacing of the $\mathrm{CD}$ as well as general stabilization of this interaction by the NT. We suggest a general mechanism of dynamic higher order organization mediated by HP1 proteins that might be the basis of the plasticity of condensed chromatin.

\section{Results}

hHP1及 binds H3K9me3 chromatin with high specificity. To obtain molecular insights into the interaction of HP1 proteins with chromatin, we generated uniformly K9-methylated histone $\mathrm{H} 3$ protein by native chemical ligation (synthetic $\mathrm{H} 3$ (aa 1-20) tail peptides fused to recombinant $\mathrm{H} 3(\Delta 1-20$, A21C)) or via
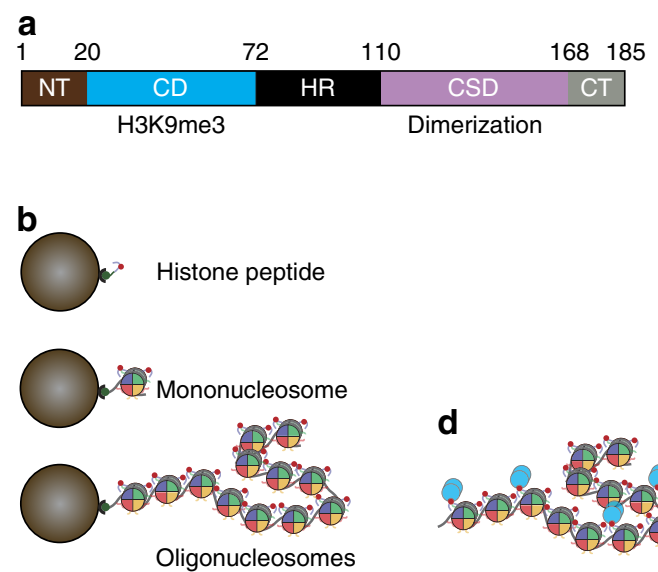

e
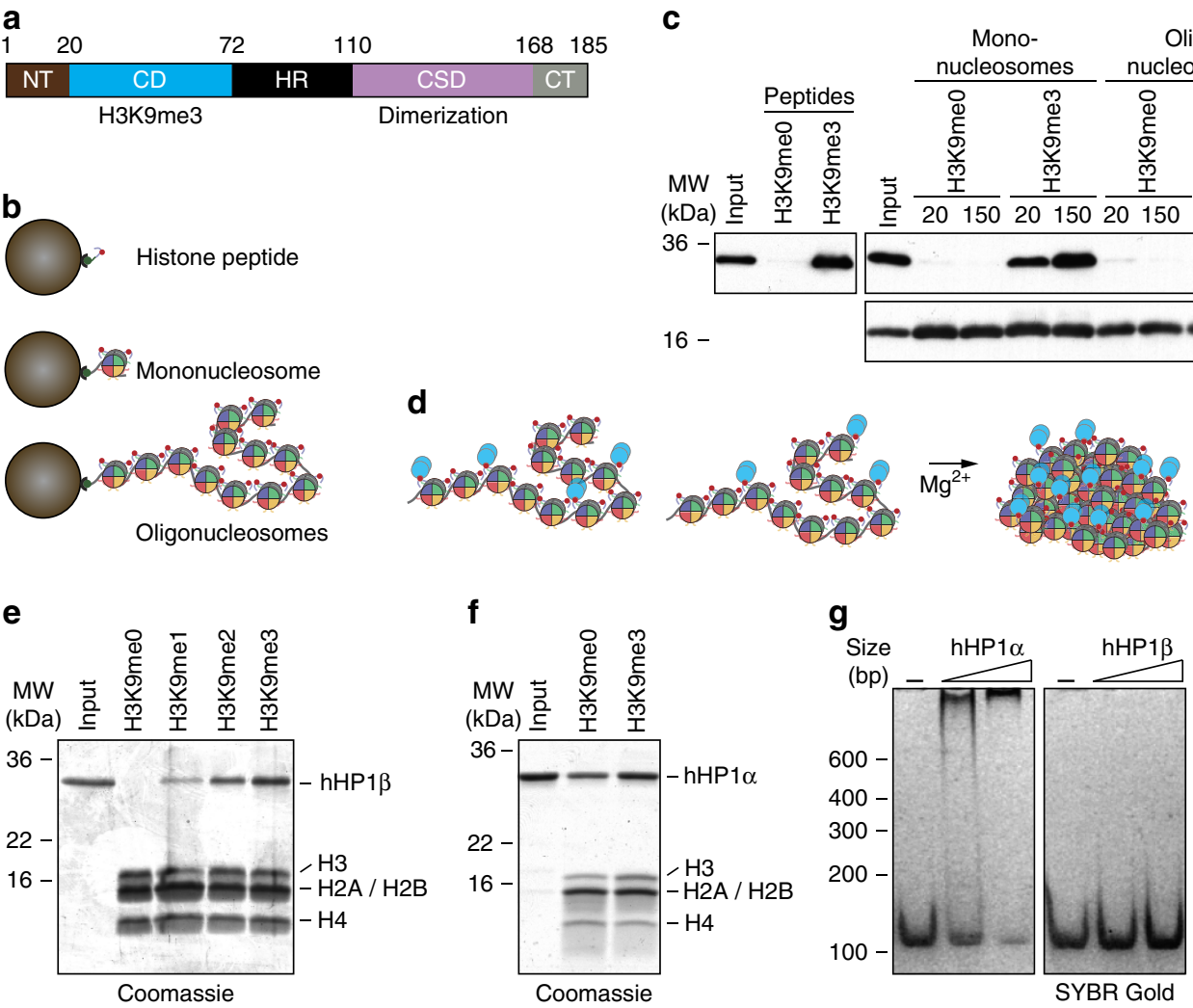

Figure 1 | hHP1p-chromatin interaction is dependent on H3K9me3. (a) Domain structure of hHP1ß; boundaries of domains are indicated by respective amino acid positions. For more details see Supplementary Fig. 2. (b) Scheme of pull-down experiments in c using different H3K9me templates immobilized on streptavidin-coated magnetic beads via C-terminal incorporation of a biotinylated lysine (peptide) or ligation of 5'-biotinylated oligonucleotides to DNA templates used in chromatin reconstitution (mono- and oligonucleosomes). (c) Immobilized H3K9me templates according to the pull-down experimental schemes in $\mathbf{b}$ were incubated with recombinant hHP1 $\beta$ WT. Material recovered after washing was analysed by western blotting. The indicated salt concentrations were used throughout the experiment. (d) Scheme of chromatin coprecipitation assay; factors bound to oligonucleosomes are precipitated with the template when clustering is induced by addition of $\mathrm{Mg}^{2+}$ ions. (e,f) Chromatin coprecipitation of hHP1 $(\mathbf{e})$ and hHP1 $\alpha(\mathbf{f})$ proteins with oligonucleosomes. Precipitated material was run on SDS-PAGE and stained with Coomassie blue. Input, 10\%. (g) The indicated recombinant proteins were incubated with a DNA fragment of 150 bp at 500: 1 and 1,000: 1 molar ratio. Complexes were separated by PAGE. DNA was stained with SYBR Gold. 
Table 1 | Interaction parameters of hHP1 $\beta$ WT and mutant proteins with the H3K9me3-modification in different biochemical environment as deduced by different methods.

\begin{tabular}{|c|c|c|c|c|c|c|c|}
\hline & & & $K_{\mathrm{d}}(\mu \mathrm{M})$ & $\mathbf{N}$ & $K_{\mathrm{d}}(\mu \mathrm{M})$ & $\mathbf{N}$ & $\begin{array}{c}\text { SPR } \\
150 \mathrm{mM} \mathrm{NaCl} \\
K_{\mathrm{d}}(\mu \mathrm{M}) \\
\end{array}$ \\
\hline & & I161A & $1.1 \pm 0.5$ & $1.0 \pm 0.1$ & $3.4 \pm 0.2$ & $0.9 \pm 0.0$ & $7.0 \pm 0.4$ \\
\hline & & $C D$ & - & - & $3.3 \pm 0.5$ & $1.1 \pm 0.1$ & $6.3 \pm 0.9$ \\
\hline Peptide & $\mathrm{H} 3 \mathrm{~K}_{\mathrm{C}} 9 \mathrm{me} 3$ & WT & $11 \pm 4$ & $1.0 \pm 0.0$ & $21 \pm 3$ & $1.0 \pm 0.1$ & - \\
\hline & & $1161 \mathrm{~A}$ & - & - & - & - & $5.2 \pm 0.6$ \\
\hline \multirow[t]{2}{*}{ Mononucleosome } & $\mathrm{H} 3 \mathrm{~K}_{\mathrm{C}} 9 \mathrm{me} 3$ & WT & $59 \pm 8$ & $2.1 \pm 0.3$ & $22 \pm 8$ & $1.4 \pm 0.3$ & - \\
\hline & & I161A & $223 \pm 30$ & $1.1 \pm 0.4$ & $58 \pm 17$ & $1.2 \pm 0.3$ & - \\
\hline \multirow[t]{2}{*}{ Oligonucleosome } & $\mathrm{H} 3 \mathrm{~K}_{\mathrm{C}} 9 \mathrm{me} 3$ & WT & NB & & $11 \pm 2$ & $1.9 \pm 0.1$ & - \\
\hline & & I161A & NB & & $132 \pm 24$ & $1.1 \pm 0.3$ & - \\
\hline
\end{tabular}

a

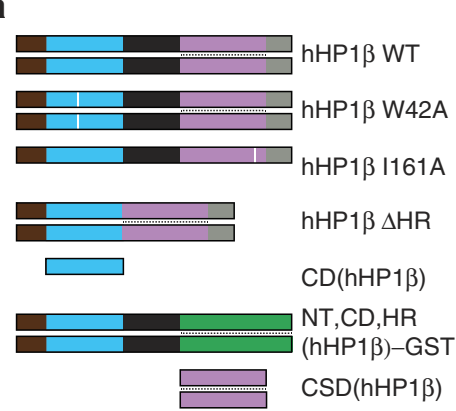

C

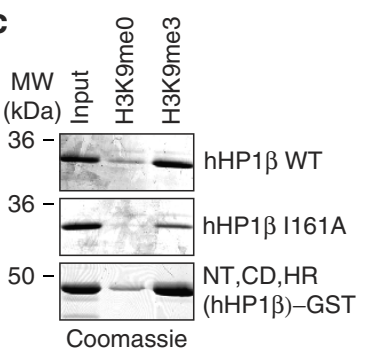

b

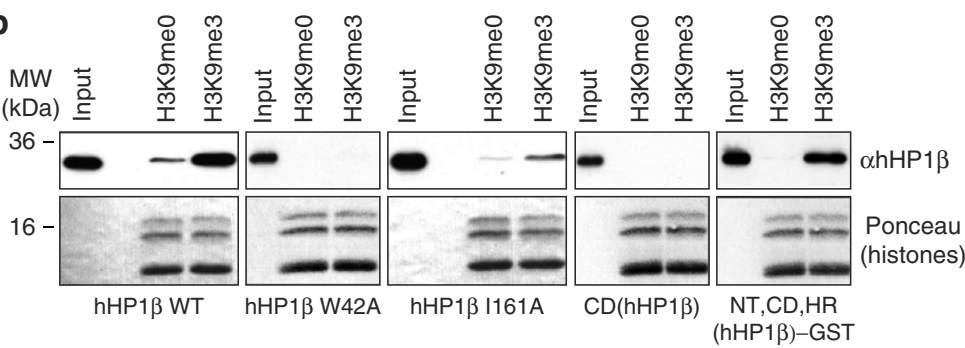

d
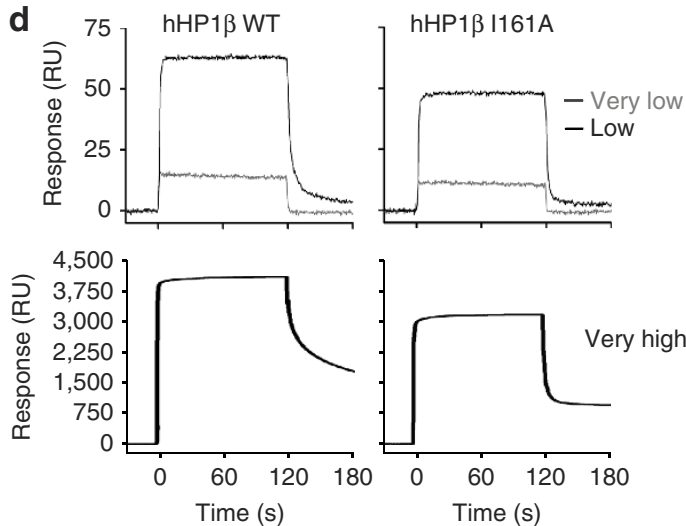

e

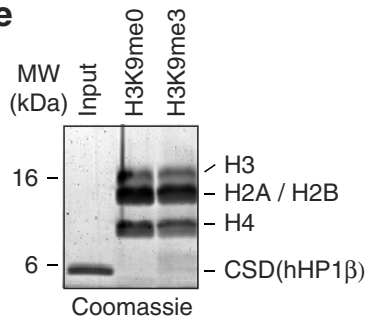

Figure 2 | Dimerization is necessary and sufficient for hHP1ß binding of H3K9me3 chromatin. (a) Schematic representation of hHP1 $\beta$ mutant proteins. White bars indicate positions of W42 and 1161, respectively. (b) Chromatin coprecipitation of WT and mutant hHP1 $\beta$ proteins with oligonucleosomes. Precipitated material was analysed by western blotting using antibodies that recognizes the CD of hHP1 $\beta$. Ponceau staining of the region of the western blot membrane containing histones is shown as loading control. Input, 10\%. (c) The indicated proteins were incubated with a biotinylated $\mathrm{H} 3 \mathrm{~K} 9 \mathrm{me} 3$ peptide immobilized on magnetic streptavidin beads. Material recovered after washing was run on SDS-PAGE and stained with Coomassie blue. Input, 10\%. (d) SPR analysis of hHP1 $\beta$ WT interaction with a biotinylated H3K9me3 peptide immobilized at different density on the chip surface (very low, 5 RU; low, 24 $\mathrm{RU}$; very high, $950 \mathrm{RU}$ ). (e) Experiment as in b using hHP1 $\beta$ CSD, but analyzed by SDS-PAGE and staining with Coomassie Blue.

aminoalkylation of $\mathrm{H} 3$ with cysteine at position 9 instead of lysine (methyl lysine analogue, $\mathrm{H}_{3} \mathrm{~K}_{\mathrm{C}} 9 \mathrm{me}$ ) using our previously established procedures ${ }^{16}$. Since our work has indicated sixfold reduced binding of hHP1 $\beta$ to an $\mathrm{H} 3$-tail peptide-containing $\mathrm{H}_{3} \mathrm{~K}_{\mathrm{C}} 9 \mathrm{me}$ compared with methylated lysine (Table 1$)^{17}$, we used $\mathrm{H} 3 \mathrm{~K}_{\mathrm{C}} 9 \mathrm{me}$ exclusively for experiments requiring large amounts of designer chromatin that were not available by the native chemical ligation strategy. $\mathrm{H} 3$ with different modification status was incorporated into mononucleosomes and 12-mer oligonucleosomal arrays using DNA containing 601 positioning sequences (Supplementary Fig. 1a,b). At saturation rates of $11 \pm 1$ nucleosomes, we observed no apparent differences in the compaction and folding behaviour of the unmodified and $\mathrm{H} 3 \mathrm{~K} 9 \mathrm{me} 3$ chromatin arrays (Supplementary Fig. 1c-e).

In pull-down experiments of immobilized H3 tail peptides, mono- and oligonucleosomes hHP1 $\beta$ was retained much more efficiently on all three matrices in the presence of $\mathrm{H} 3 \mathrm{~K} 9 \mathrm{me} 3$ as compared with the unmodified (H3K9me0) counterpart (Fig. 1b,c; Supplementary Table 1 summarizes the different assays and experimental conditions used to analyse hHP1 $\beta /$ chromatin interaction). Since chromatin fibres undergo reversible transitions from elongated state to compacted arrays that are 
further aggregated by interstrand interaction ${ }^{18}$, we asked whether specific binding was retained with oligonucleosomes at higher order folded state. In the presence of $5 \mathrm{mM} \mathrm{Mg}^{2+}$, chromatin fibres precipitate and can be recovered from solution by centrifugation. Under these conditions hHP1 $\beta$ coprecipitated only with $\mathrm{H} 3 \mathrm{~K} 9 \mathrm{me} 1 / 2 / 3$ but not $\mathrm{H} 3 \mathrm{~K} 9 \mathrm{me} 0$ oligonucleosomes (Fig. 1d,e). Further analysis with $\mathrm{H} 3 \mathrm{~K} 4 \mathrm{me} 3$ and $\mathrm{H} 3 \mathrm{~K}_{\mathrm{C}} 27 \mathrm{me} 3$ oligonucleosomes verified the specificity of this interaction (Supplementary Fig. If and g). Recovery of hHP1 $\beta$ with aggregated chromatin was independent of the DNA sequence used for chromatin reconstitution (Supplementary Fig. 1h).

When analysing recombinant hHP1 $\alpha$ in the chromatin coprecipitation scheme, the protein displayed much less specificity for $\mathrm{H} 3 \mathrm{~K} 9 \mathrm{me} 3$ compared with hHP1 $\beta$ (Fig. 1f). In agreement and as observed previously, hHP1 $\alpha$ but not hHP1 $\beta$ showed a high level of general DNA binding in gel shift experiments (Fig. 1g) ${ }^{13}$.

Dimerization mediates H3K9me3-chromatin binding of hHP1及. To determine the molecular requirements for the highly specific hHP1ß/H3K9me3-chromatin interaction, we prepared different point as well as deletion mutant proteins (Fig. 2a and Supplementary Fig. 2a). Mutation of residue W42, which was shown previously to impair binding to $\mathrm{H} 3 \mathrm{~K} 9 \mathrm{me} 3$ (ref. 7), resulted in the loss of recovery of hHP1 $\beta$ with $\mathrm{H} 3 \mathrm{~K} 9 \mathrm{me} 3$ oligonucleosomes (Fig. 2b). Under the same conditions neither the monomeric CD alone nor an I161A mutant protein, which is incapable of dimerization ${ }^{8}$, were significantly recovered with H3K9me3 oligonucleosomes. Since both proteins bound an H3K9me3-peptide as efficiently as hHP1 $\beta$ wild type (WT; Table 1), the results implied that the $\mathrm{CD} / \mathrm{H} 3 \mathrm{~K} 9 \mathrm{me} 3$ interaction is not sufficient for chromatin binding. In agreement, hHP1 $\beta$ I161A was ineffective in competing with hHP1 $\beta$ WT for interaction with $\mathrm{H} 3 \mathrm{~K} 9 \mathrm{me} 3$ oligonucleosomes (Supplementary Fig. 2b). Also, isothermal titration calorimetry (ITC) measurements deduced a 12 -fold reduced interaction of hHP1 $\beta$ I161A with $\mathrm{H} 3 \mathrm{~K}_{\mathrm{C}} 9 \mathrm{me} 3$ oligonucleosomes compared with hHP1 $\beta$ WT (Table 1).

We reasoned that the difference in binding of hHP1 $\beta$ WT and I161A proteins to free peptide and oligonucleosomes must be due to the high density of $\mathrm{H} 3 \mathrm{~K} 9 \mathrm{me} 3$ on the chromatin template. Indeed, pull-down experiments with H3-tail peptides densely immobilized on magnetic beads showed significantly reduced recovery of I161A compared with hHP1 $\beta$ WT (Fig. 2c).

Further analysis of the interaction kinetics of hHP1 $\beta$ WT and I161A with $\mathrm{H} 3 \mathrm{~K} 9 \mathrm{me} 3$ peptides immobilized on surface plasmon resonance (SPR) chip surfaces deduced similar, very fast association kinetics of both proteins. The signal of immobilization rapidly reached a plateau with both proteins and on $\mathrm{H} 3 \mathrm{~K} 9 \mathrm{me} 3$ surfaces of different density (Fig. 2d). The hHP1 $\beta$ WT and I161A proteins differed, however, in the release from the matrices. While the I161A protein dissociated rapidly from the H3K9me3 ligand, hHP1 $\beta$ WT was released more slowly. This effect was more pronounced at higher $\mathrm{H} 3 \mathrm{~K} 9 \mathrm{me} 3$ surface densities. The residual signals seen under these conditions were lower at higher flow rates and could also be competed specifically with free $\mathrm{H} 3 \mathrm{~K} 9 \mathrm{me} 3$ peptide ligand but not H3K9me0 (Supplementary Fig. $2 \mathrm{c}$ and d), indicating that this effect is due to mass transfer limitations as well as rebinding phenomena known to occur with SPR measurements ${ }^{19}$. In agreement with the different binding kinetics, we deduced 10 -fold stronger binding of the hHP1 $\beta$ WT protein to the $\mathrm{H} 3 \mathrm{~K} 9 \mathrm{me} 3$ matrix compared with the I161A protein in SPR titration experiments (Table 1).

Since we did not detect any binding of the CSD to oligonucleosomes (Fig. 2e), we reasoned that its contribution to $\mathrm{H} 3 \mathrm{~K} 9 \mathrm{me} 3 /$ chromatin interaction is solely via mediating dimerization. To test this hypothesis, we analysed an hHP1 $\beta$ chimera where the CSD was replaced with an unrelated dimerization module. We used glutathione S-transferase (GST), as it is known to form dimers of similar strength as hHP1 $\beta$ WT in solution $\left(K_{\mathrm{d}}<1 \mathrm{nM}\right)^{9,20}$. In chromatin coprecipitation (Fig. $2 \mathrm{~b}$ ) as well as in $\mathrm{H} 3 \mathrm{~K} 9 \mathrm{me} 3$ peptide pull-down (Fig. $2 \mathrm{c}$ ) experiments NT, $\mathrm{CD}, \mathrm{HR}(\mathrm{hHP} 1 \beta)-\mathrm{GST}$ indeed showed interaction similar to hHP1 $\beta$ WT. On the basis of these findings, we deduced that CSDmediated dimerization of hHP1 $\beta$ WT results in kinetic trapping of the protein on dense $\mathrm{H} 3 \mathrm{~K} 9 \mathrm{me} 3$ surfaces such as provided on peptide-bound matrices or oligonucleosomes and there in particular after condensation and aggregation.

hHP1 $\beta$ induces aggregation of $\mathrm{H} 3 \mathrm{~K} 9 \mathrm{me} 3$ oligonucleosomes. Having established the interaction parameters of hHP1 $\beta$ with oligonucleosomes, we investigated the effects of its binding onto chromatin conformation. At $150 \mathrm{mM} \mathrm{NaCl}$ oligonucleosomes are highly soluble. These are in compacted (zig-zag) state but do not interact with each other (Supplementary Fig. 1e). Under these conditions increasing concentrations of hHP1 $\beta$ WT efficiently aggregated $\mathrm{H} 3 \mathrm{~K} 9 \mathrm{me} 3$ but not $\mathrm{H} 3 \mathrm{~K} 9 \mathrm{me} 0$ oligonucleosomes to a degree that the complexes precipitated and could be collected by centrifugation (Fig. 3a). This effect was generally reversible as shown in resolubilization experiments (Supplementary Fig. 3a and $b$ ). The hHP1 $\beta$ I161A mutant protein, in contrast, failed to induce the aggregation of oligonucleosomes.

To obtain further insights into the chromatin aggregation induced by hHP1 $\beta$, we set up fluorescence correlation spectroscopy (FCS) measurements for single-molecule analysis. By labelling the DNA in oligonucleosomes with ATTO 610, this allowed delineating the diffusion behaviour and thereby size of the different chromatin species (Supplementary Fig. $3 c$ and d). In this assay, hHP1 $\beta$ WT induced H3K9me3 oligonucleosomes to form large assemblies that reached a maximum hydrodynamic radius of $450 \mathrm{~nm}$ at the highest protein concentration (Fig. 3b). No such complex formation by clustering was seen with the I161A mutant protein. With the $\mathrm{H} 3 \mathrm{~K} 9 \mathrm{me} 0$ oligonuclesomes larger assemblies only appeared at high hHP1 $\beta$ WT concentrations. We note that the half-maximal effects in the FCS experiment and the chromatin precipitation assay were seen at 3.5 and $0.4 \mu \mathrm{M} h H P 1 \beta$ WT, respectively. Since the binding of hHP1 $\beta$ to peptides is slightly enhanced at lower temperature ${ }^{21}$, we assume that the difference is explained by the experimental setup of the FCS experiment at $23^{\circ} \mathrm{C}$ and the sedimentation assay at $4^{\circ} \mathrm{C}$. Also, we do not know the minimal hydrodynamic size of aggregates that results in the recovery in the centrifugation assay.

hHP1 $\beta$ clusters chromatin exposing high density of H3K9me3. In analysing the interaction of hHP1 $\beta$ WT with $\mathrm{H} 3 \mathrm{~K} 9 \mathrm{me} 3$ in different biochemical context, we noticed a significant difference in binding strength at low and high-salt concentrations. While the protein bound better to free $\mathrm{H} 3 \mathrm{~K} 9 \mathrm{me} 3$ peptide at $20 \mathrm{mM} \mathrm{NaCl}\left(K_{\mathrm{d}}=1.4 \pm 0.6 \mu \mathrm{M}\right)$ compared with $150 \mathrm{mM} \mathrm{NaCl}$ $\left(K_{\mathrm{d}}=3.3 \pm 0.2 \mu \mathrm{M}\right)$, this trend was reversed in the context of chromatin. $\mathrm{H} 3 \mathrm{~K}_{\mathrm{C}} 9 \mathrm{me} 3$ mononucleosomes were bound 2.7-fold better at the higher compared with the lower salt concentration. At $20 \mathrm{mM} \mathrm{NaCl}$ we could not detect any binding of hHP1 $\beta$ WT to $\mathrm{H} 3 \mathrm{~K}_{\mathrm{C}} 9 \mathrm{me} 3$ oligonucleosomes but deduced a $K_{\mathrm{d}}$ of $11 \pm 2 \mu \mathrm{M}$ for binding to the same template at $150 \mathrm{mM} \mathrm{NaCl}$ (Table 1 and Supplementary Fig. 4). Obviously, two counteracting effects determine binding of hHP1 $\beta$ to $\mathrm{H} 3 \mathrm{~K} 9$ me3 chromatin. On one end, the $\mathrm{CD} / \mathrm{H} 3 \mathrm{~K} 9 \mathrm{me} 3$ interaction is sensitive to higher salt conditions. On the other end, at low salt concentration, the H3 tails in chromatin are not fully available, likely due to electrostatic 
a

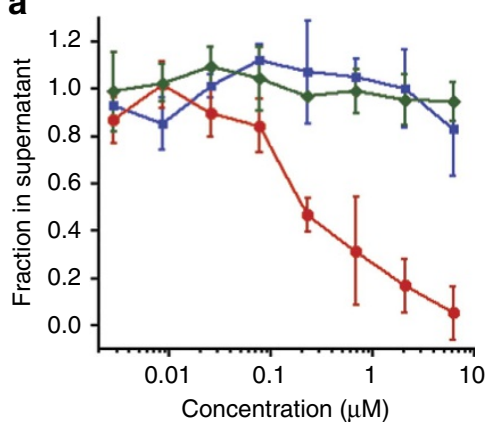

b

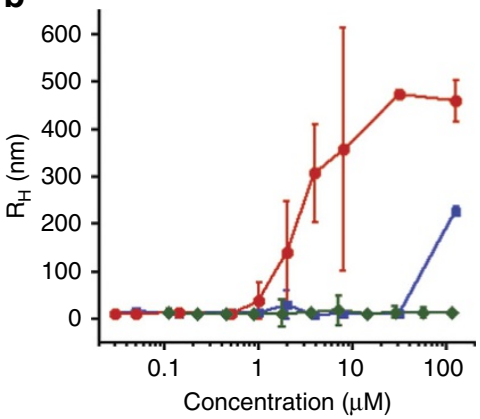

C

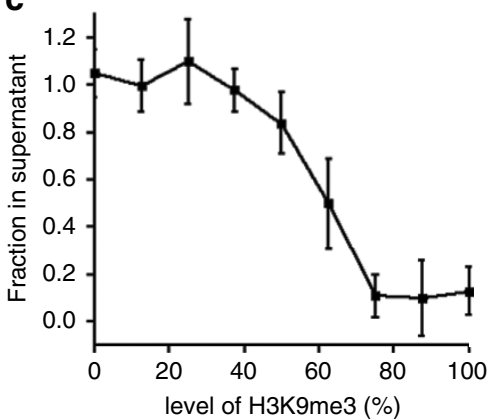

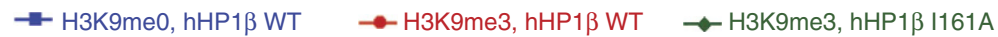

d

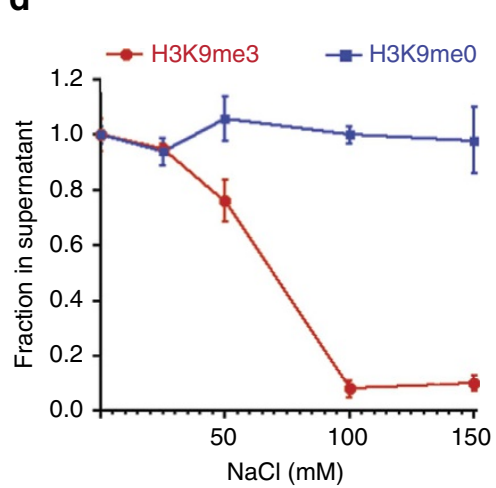

e

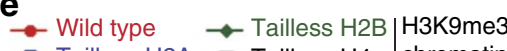

$\rightarrow$ Tailless H2A $\rightarrow$ Tailless H4

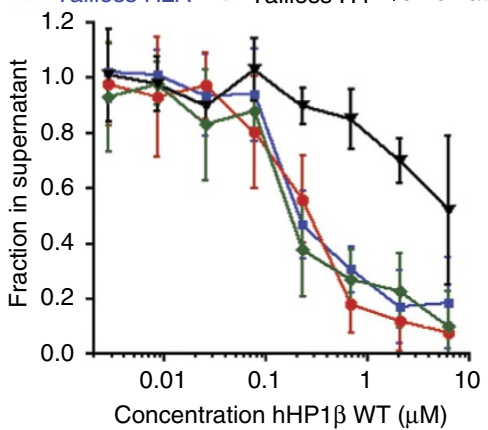

$\mathbf{f}$

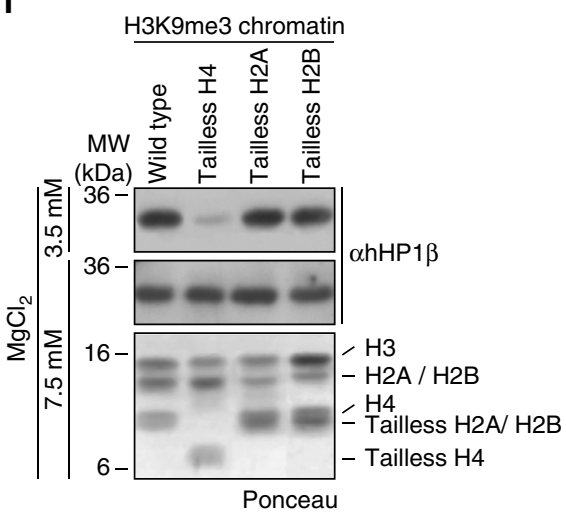

g

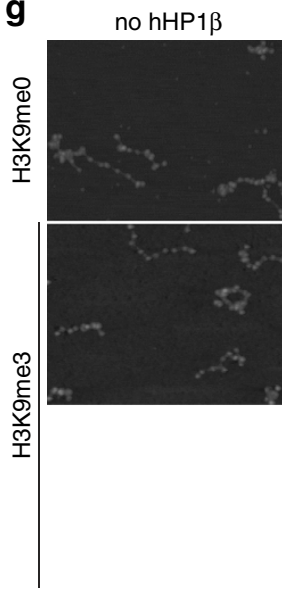

h

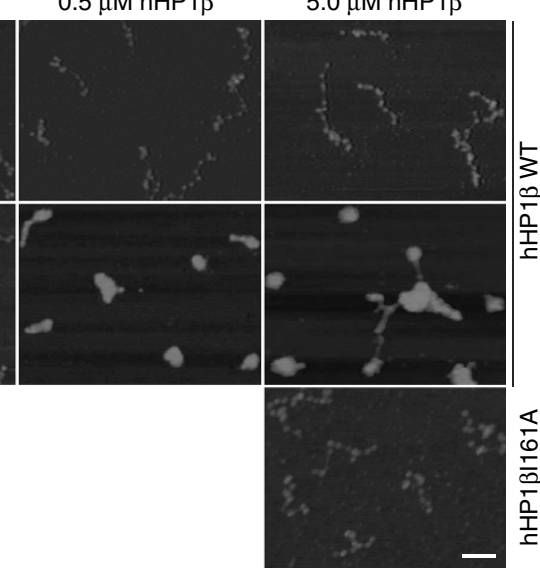

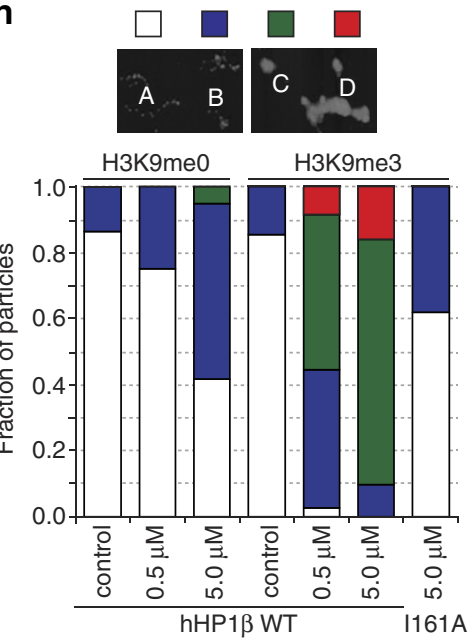

Figure 3 | hHP1 $\beta$ clusters oligonuclesomal arrays in dependence of H3K9me3. (a) Oligonucleosomes (2.5 nM) were incubated with increasing concentrations of hHP1 $\beta$ WT or I161A at $150 \mathrm{mM} \mathrm{NaCl}$. DNA remaining in the supernatant after centrifugation was incubated with EtBr and measured by fluorescence reading. Data were normalized to amounts in absence of added protein. Averages of three independent experiments are plotted; error bars represent s.d.; $n=3$. (b) Analysis of the hydrodynamic radius of oligonucleosomes (10 nM; DNA labelled with ATTO 610) in the presence of increasing concentrations of hHP1 $\beta$ WT or I161A by FCS at $150 \mathrm{mM} \mathrm{NaCl}$. For details on experimental setup see Supplementary Fig. 3. Error bars represent s.d.; $\mathrm{n}=3$. (c) Oligonucleosomes were reconstituted after mixing $\mathrm{H} 3 \mathrm{~K} 9 \mathrm{meO}$ and $\mathrm{H} 3 \mathrm{~K} 9 \mathrm{me} 3$ octamers at different ratio. Chromatin precipitation analysis at 150 mM $\mathrm{NaCl}$ was carried out with hHP1 $\beta$ WT at saturating concentration. Data are presented as in $\mathbf{a}$. (d) Precipitation behaviour of oligonucleosomes (2.5 $\mathrm{nM}$ ) was analysed at different concentrations of $\mathrm{NaCl}$ with hHP1 $\beta$ WT at saturating concentration. Data are presented as in a. (e) H3K9me3-containing chromatin was reconstituted using wild-type core histones or tailless $\mathrm{H} 2 \mathrm{~A}, \mathrm{H} 2 \mathrm{~B}$ or $\mathrm{H} 4$. Oligonucleosomes $(2.5 \mathrm{nM})$ were incubated with increasing concentrations of hHP1 $\beta$ WT at $150 \mathrm{mM} \mathrm{NaCl}$. Data are presented as in $\mathbf{a}$. (f) Chromatin coprecipitation of hHP1 $\beta$ with H3K9me3-containing oligonucleosomes reconstituted with wild-type or tailless core histones at the indicated concentrations of $\mathrm{MgCl}_{2}$. Precipitated material was analysed by western blotting. The region of the western blot membrane of the experiment at $7.5 \mathrm{mM} \mathrm{MgCl}_{2}$ containing histones was stained with Ponceau. (g) Oligonucleosomes at $50 \mathrm{mM} \mathrm{NaCl}$ were incubated with hHP1 $\beta$ WT or I161A. Complexes were fixed with $0.05 \%(\mathrm{v} / \mathrm{v})$ glutaraldehyde, spotted on mica surfaces and analysed by scanning force microscopy. Control, no protein added; scale bar, $100 \mathrm{~nm}$. (h) Quantification of results representatively shown in $\mathbf{g}$ according to the classification on the top: $A$, extended; $B$, partially condensed; $C$, fully condensed; $D$; aggregates; $n>50$ for each condition. 
binding to $\mathrm{DNA}^{18,22}$. Conditions of higher salt increase the availability of the $\mathrm{H} 3$ tails and induce chromatin condensation. The high density of $\mathrm{H} 3 \mathrm{~K} 9 \mathrm{me} 3$ in this situation provides a favourable binding platform for hHP1 $\beta$ interaction, which in turn promotes clustering of chromatin.

If this interpretation were correct, we would expect the effect of hHP $1 \beta$ chromatin clustering to be dependent on the level of $\mathrm{H} 3 \mathrm{~K} 9 \mathrm{me} 3$ in the oligonucleosomes. Indeed, when mixing $\mathrm{H} 3 \mathrm{~K} 9 \mathrm{me} 0$ and $\mathrm{H} 3 \mathrm{~K} 9 \mathrm{me} 3$ at different ratios for oligonucleosomal reconstitution, we observed that a content of more than $50 \%$ $\mathrm{H} 3 \mathrm{~K} 9 \mathrm{me} 3$ was required for hHP1 $\beta$ to induce efficient chromatin clustering (Fig. 3c).

To further test the idea that hHP $1 \beta$ preferentially binds to condensed chromatin and mediates clustering, we performed salt titration of $\mathrm{H} 3 \mathrm{~K} 9 \mathrm{me} 0$ and $\mathrm{H} 3 \mathrm{~K} 9 \mathrm{me} 3$ oligonucleosomes in presence of the protein. We found a transition of hHP $1 \beta$ inducing clustering of $\mathrm{H} 3 \mathrm{~K} 9 \mathrm{me} 3$ oligonucleosomes at salt concentrations above $50 \mathrm{mM} \mathrm{NaCl}$, which are known to promote intrafiber condensation (Fig. 3d). No clustering of $\mathrm{H} 3 \mathrm{~K} 9 \mathrm{me} 0$ chromatin was seen in the presence of hHP $1 \beta$ even at $150 \mathrm{mM} \mathrm{NaCl}$.
$\mathrm{Mg}^{2+}$-induced chromatin aggregation requires minimally the $\mathrm{N}$-terminal tails of $\mathrm{H} 3$ or $\mathrm{H} 4$. In contrast, the tails of $\mathrm{H} 2 \mathrm{~A}$ and $\mathrm{H} 2 \mathrm{~B}$ are not sufficient for this process ${ }^{23,24}$. To further analyse hHP1 $\beta$-dependent chromatin clustering, we set up $\mathrm{H} 3 \mathrm{~K} 9 \mathrm{me} 3$ oligonucleosomal templates containing tailless $\mathrm{H} 2 \mathrm{~A}, \mathrm{H} 2 \mathrm{~B}$ or $\mathrm{H} 4$. Compared with oligonucleosomes containing WT histones these required higher $\mathrm{MgCl}_{2}$ concentration for inducing intrafiber aggregation and precipitation (Supplementary Fig. 5), as was shown previously ${ }^{24}$. We determined the Mg50 value for WT $\mathrm{H} 3 \mathrm{~K} 9 \mathrm{me} 3$ oligonucleosomes at around $2 \mathrm{mM}$, whereas the $\mathrm{Mg} 50$ for $\mathrm{H} 3 \mathrm{~K} 9 \mathrm{me} 3$ oligonucleosomes containing tailless $\mathrm{H} 2 \mathrm{~A}$ or $\mathrm{H} 2 \mathrm{~B}$ were around $3 \mathrm{mM}$ and that for $\mathrm{H} 3 \mathrm{~K} 9 \mathrm{me} 3$ oligonucleosomes containing tailless $\mathrm{H} 4$ was around $4 \mathrm{mM}$. While hHP1 $\beta$ clustered $\mathrm{H} 3 \mathrm{~K} 9 \mathrm{me} 3$ oligonucleosomes containing tailless $\mathrm{H} 2 \mathrm{~A}$ or $\mathrm{H} 2 \mathrm{~B}$ as efficiently as $\mathrm{H} 3 \mathrm{~K} 9 \mathrm{me} 3$-oligonucleosomes containing WT core histones, the effect on $\mathrm{H} 3 \mathrm{~K} 9 \mathrm{me} 3$ oligonucleosomes containing tailless $\mathrm{H} 4$ was impaired (Fig. 3e). Also and in agreement with the altered aggregation behaviour (Supplementary Fig. 5), chromatin coprecipitation showed reduced recovery of hHP1 $\beta$ with $\mathrm{H} 3 \mathrm{~K} 9 \mathrm{me} 3$ oligonucleosomes in the absence of the $\mathrm{H} 4$ $\mathrm{N}$-terminal tail at $3.5 \mathrm{mM} \mathrm{MgCl}$, whereas recovery at $7.0 \mathrm{mM}$

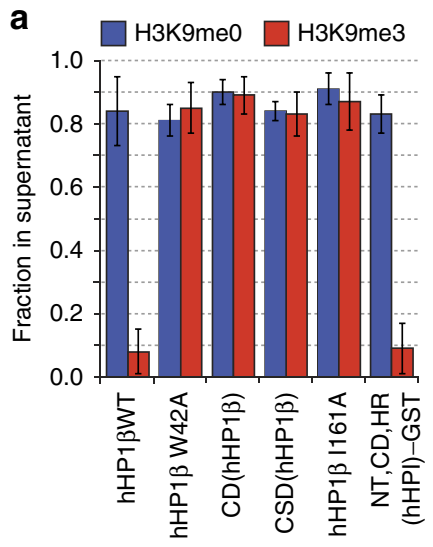

C

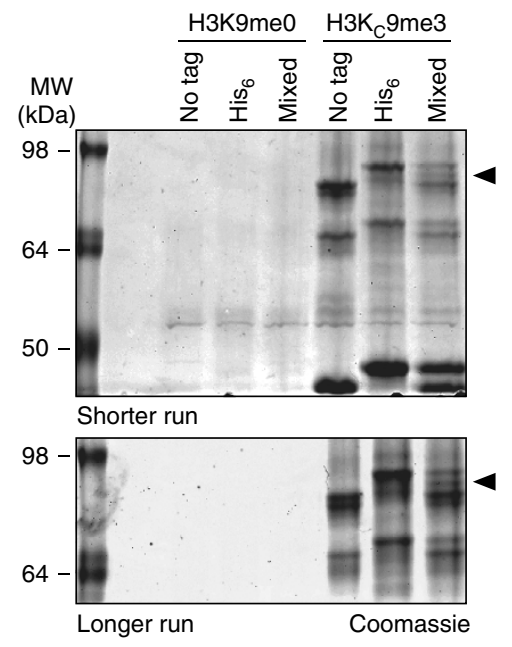

b
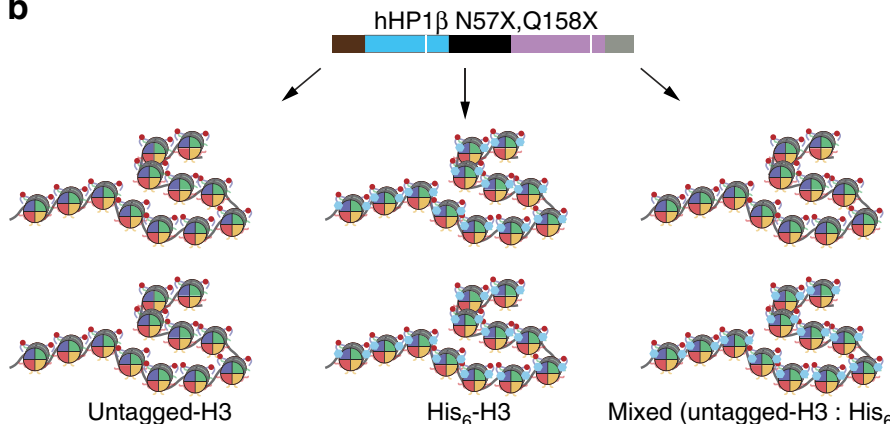

$\mathrm{His}_{6}-\mathrm{H} 3$

$\downarrow$

UV-crosslinking of hHP1 $\beta$ to itself (via CSD) and to histone $\mathrm{H} 3$ (via CD)

$\downarrow$

SDS-PAGE, densitometry scan

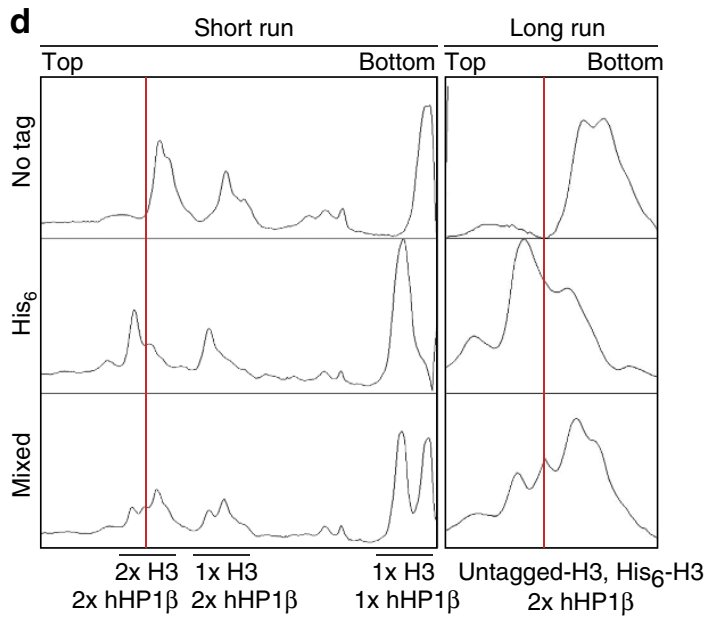

Figure 4 | hHP1及 bridges nucleosomes on the same and different chromatin fibres. (a) Chromatin precipitation analysis of oligonucleosomes with hHP1 $\beta$ wild-type (WT) or mutant proteins under saturating conditions. DNA remaining in the supernatant after centrifugation was incubated with EtBr and measured by fluorescence reading. Data were normalized to amounts present in the input. Error bars represent s.d.; $n=3$. (b) Scheme of UV-mediated hHP1 $\beta$-histone $\mathrm{H} 3$ cross-linking experiments. (c) Photo cross-linking according to the scheme in $\mathbf{b}$ was done with $\mathrm{H} 3 \mathrm{~K} 9 \mathrm{meO}$ or $\mathrm{H} 3 \mathrm{~K}_{\mathrm{C}} 9 \mathrm{me} 3$ oligonucleosomal arrays and hHP1 $\beta$ N57X Q158X. Samples were run on SDS-PAGE (top, shorter run; bottom, longer run) and stained with Coomassie blue. Black arrows indicate crosslinked hHP1 $\beta$ dimer crosslinked to one untagged histone $\mathrm{H} 3$ and one His ${ }_{6}$-tagged histone H3. (d) Histograms of intensity scans of Coomassie blue stained SDS-PAGE gels shown in $\mathbf{c}$. 
$\mathrm{MgCl}_{2}$ was comparable to the level obtained with $\mathrm{H} 3 \mathrm{~K} 9 \mathrm{me} 3$ oligonucleosomes containing WT core histones (Fig. 3f).

Since the salt titration had shown that at $50 \mathrm{mM} \mathrm{NaCl}$ discriminatory effects of hHP $1 \beta$ onto $\mathrm{H} 3 \mathrm{~K} 9 \mathrm{me} 0$ and $\mathrm{H} 3 \mathrm{~K} 9 \mathrm{me} 3$ oligonucleosomes become apparent (Fig. 3d), we selected this condition to visualize the chromatin complexes formed by hHP1 $\beta$ using scanning force microscopy (Fig. $3 \mathrm{~g}$ ). Due to the clear dose response (Fig. 3a,b), we reasoned that at this intermediate condition different states of hHP1 $\beta$-dependent chromatin clustering could be observed at different concentrations of the protein. At $0.5 \mu \mathrm{M}$ hHP $1 \beta \mathrm{WT}$, we mostly observed structures whose size was consistent with individual but highly condensed H3K9me3 chromatin species. At $5 \mu \mathrm{M}$ hHP $1 \beta$ WT larger clusters that must contain multiple oligonucleosomes were visible. Similar to the 'in solution' assays, the frequency of condensed chromatin fibres and large chromatin clusters was much lower for $\mathrm{H} 3 \mathrm{~K} 9 \mathrm{me} 0$ chromatin with hHP $1 \beta$ WT or for H3K9me3 chromatin with I161A mutant protein (Fig. 3h).

hHP1 $\beta$ bridges H3K9me3 of different chromatin fibres. We next investigated whether dimerization is sufficient for the effect of the hHP1 $\beta$ CSD in chromatin clustering. At $150 \mathrm{mM} \mathrm{NaCl}$ $5 \mu \mathrm{M} \mathrm{hHP} 1 \beta$ WT are sufficient for inducing maximal chromatin clustering (Fig. 3a). Under these conditions, neither the I161A mutant, nor the isolated CD or CSD had any effect on modified or unmodified chromatin (Fig. 4a). As expected, mutation of W42A that abolishes interaction with $\mathrm{H} 3 \mathrm{~K} 9 \mathrm{me} 3$ also failed to cluster oligonucleosomes. However, artificial dimerization of the NT, CD and HR domains of hHP1 $\beta$ via GST (NT, CD, HR(hHP1 $\beta$ )-GST) was sufficient to induce the maximal response in this assay.

To determine whether hHP $1 \beta$ promotes interfiber association by bridging different chromatin strands, we set up a cross-linking strategy, where we mapped linkage of dimeric protein to H3 (Fig. 4b). The photo-crosslinkable unnatural amino acid p-benzoyl-L-phenylalanine (pBpa) covalently binds to aliphatic side chains of amino acids within a distance of $<4 \AA$ on ultraviolet irradiation $(\lambda=365 \mathrm{~nm})$. On the basis of the available three-dimensional structures of $\mathrm{CD} / \mathrm{H} 3 \mathrm{~K} 9 \mathrm{me} 3$ and $\mathrm{CSD} / \mathrm{CSD}$ complexes, we used stop codon suppression to generate a recombinant $\mathrm{hHP} 1 \beta$ protein containing $\mathrm{pBpa}$ at positions 57 and 158 (N57X and Q158X) for cross-linking of the CD and CSD, respectively (Supplementary Fig. $6 \mathrm{a})^{25}$. Incorporation of pBpa at these sites did not affect the binding of hHP1 $\beta$ to H3K9me3 oligonucleosomal arrays (Supplementary Fig. 6b). To distinguish $\mathrm{H} 3$ from different chromatin fibres, we reconstituted oligonucleosomes with untagged and $\mathrm{His}_{6}$-tagged $\mathrm{H} 3$ unmodified and containing the $\mathrm{H}_{3} \mathrm{~K}_{\mathrm{C}} 9 \mathrm{me} 3$ methyl lysine analogue (Fig. $4 \mathrm{~b}$ ). Chromatin coprecipitation analysis verified that the $\mathrm{His}_{6}$-tagging of $\mathrm{H} 3$ did not have any effect on $\mathrm{hHP} 1 \beta$ recruitment (Supplementary Fig. 6c).

While hHP1 $\beta$ N57X Q158X did not cross-link to H3 in unmodified oligonucleosomes (Fig. 4c, Supplementary Fig. 6d shows the loading control of the experiment), western blotting with anti- $\mathrm{His}_{6}$ and anti-H3 antibodies identified three major crosslinks of hHP1 $\beta$ N57X Q158X to $\mathrm{H}_{3} \mathrm{~K}_{\mathrm{C}} 9 \mathrm{me} 3$ oligonucleosomes under conditions of chromatin clustering (Supplementary Fig. 6 e): $1 \times \mathrm{H} 3$ crosslinked to $1 \times \mathrm{hHP} 1 \beta$ monomer, $1 \times \mathrm{H} 3$ crosslinked to $1 \times \operatorname{hHP} 1 \beta$ dimer and $2 \times \mathrm{H} 3$ crosslinked to $1 \times$ hHP1 $\beta$ dimer. Importantly, with an equimolar mixture of untagged and $\mathrm{His}_{6}$-tagged $\mathrm{H}_{3} \mathrm{~K}_{\mathrm{C}} 9 \mathrm{me} 3$ oligonucleosomes crosslink of an hHP1 $\beta$ N57X Q158X dimer to both H3 species was observed (Fig. 4c,d). Further analysis of the hHP1 $\beta$ I161A and NT, CD, HR(hHP1 $\beta$ )-GST mutant proteins containing the
pBpa only at positions 57 within the $\mathrm{CD}$ verified that dimerization is absolutely required for cross-linking to $\mathrm{H} 3$ in this scheme (Supplementary Fig. 6f).

HR and NT of hHP1 $\beta$ modulate the function of CD and CSD. To obtain further insights into the binding interfaces of hHP $1 \beta$ with $\mathrm{H} 3 \mathrm{~K} 9 \mathrm{me} 3$ chromatin, we set up cross-linking experiments that were analysed by mass spectrometry. In particular, we targeted electrostatic protein-protein interactions using 1-Ethyl3-[dimethylaminopropyl]carbodimine (EDC), which is a zero length amine-carboxyl crosslinker (Supplementary Data 1 contains a summary of all crosslinks identified). In free hHP1 $\beta$ a large number of crosslinks originating from all domains of the protein and connecting to other regions of the factor were identified (Supplementary Fig. 7a). The results were in agreement with an overall high flexibility of the protein as determined by SAXS and nuclear magnetic resonance measurements ${ }^{16}$.

Far fewer crosslinks within hHP1 $\beta$ in the presence of H3K9me3 oligonucleosomes under conditions of chromatin clustering (Fig. 5a) and chromatin coprecipitation (Supplementary Fig. 7b) implied less flexibility of the protein in the bound state. In particular, all crosslinks involving the $\mathrm{CD}$ were lost. Also, crosslinks within the NT and from the NT to the CSD were suppressed. In contrast, a number of interfaces between residues in the HR and CSD remained as in the free state. While very few contacts with chromatin were found for $\mathrm{H} 2 \mathrm{~B}$ and $\mathrm{H} 4$, by far the most connections of different regions of hHP $1 \beta$ were with H3. Here especially residues in the NT were found in many crosslinks to the N-terminal tail of $\mathrm{H} 3$ proximal and distal to the $\mathrm{K} 9$ site. The CSD and CT also had some contacts in this area and $\mathrm{CD}, \mathrm{HR}$ and CSD were found linked to few sites within the H3 core region (aa 60-80).

To further investigate these findings, we established a series of hHP $1 \beta$ proteins mutated within the NT and HR (Fig. 5b). None of these mutant proteins differed significantly from hHP1 $\beta$ WT in their binding to a free $\mathrm{H} 3 \mathrm{~K} 9 \mathrm{me} 3$ tail peptide (Supplementary Fig. 7c). To detect a wider range of effects, we refined the chromatin clustering assay using the mutant hHP $1 \beta$ proteins at non-saturating level and lowering the $\mathrm{NaCl}$ concentration to $100 \mathrm{mM}$. Randomizing the sequence of the HR (hHP1 $\beta$ HR(scramble)) had no effect on the ability of hHP $1 \beta$ to cluster chromatin. Since work on $\mathrm{HP} 1 \alpha$ proteins has implied this region in DNA/RNA binding $26-28$, we also eliminated all the negative (hHP1 $\beta$ HR (all E, D to A)) or positively charged residues ( $\mathrm{hHP} 1 \beta$ HR (all $\mathrm{K}, \mathrm{R}$ to A)) separately as well as altogether (hHP1 $\beta$ HR (all E,D,K,R to A); Supplementary Table 2). In agreement with strong, unspecific DNA binding (Fig. 5c) the hHP1 $\beta$ HR (all E, D to A) mutant was recovered much more efficiently on $\mathrm{H} 3 \mathrm{~K} 9 \mathrm{me} 3$ chromatin compared with the WT protein but also showed high recovery on the H3K9me0 template (Fig. 5d). It had very strong chromatin clustering activity and precipitated $\mathrm{H} 3 \mathrm{~K} 9 \mathrm{me} 0$ and $\mathrm{H} 3 \mathrm{~K} 9 \mathrm{me} 3$ oligonucleosomes equally well (Fig. 5e). In stark contrast, the hHP1 $\beta$ HR (all K, R to A) mutant protein, which did not bind DNA, was less recovered with the H3K9me3 template and lost its ability to cluster chromatin. Neutralizing all charges of the HR in the hHP1 $\beta$ HR (all E, D, K, R to A) mutant not only recapitulated the lack of DNA binding of the WT protein but also fully restored its activity in chromatin coprecipitation and clustering.

On the basis of these results, we concluded that the HR of hHP1 $\beta$ does not directly contribute to chromatin binding and clustering but provides a flexible and spacing linker. Increase of the net negative charge of this region results in repelling of DNA, whereas increase of the net positive charge causes unspecific 
a

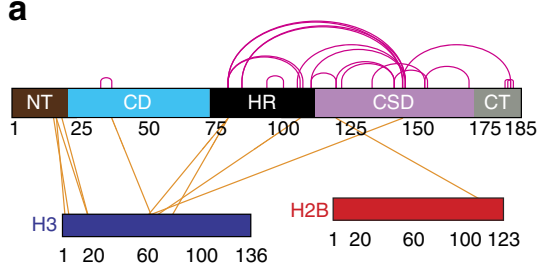

b

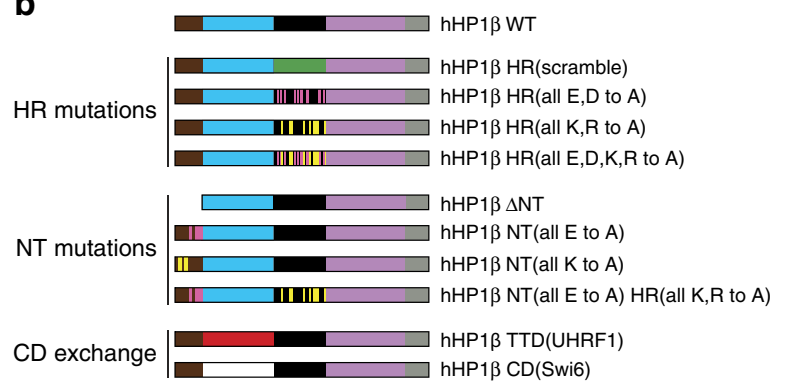

C

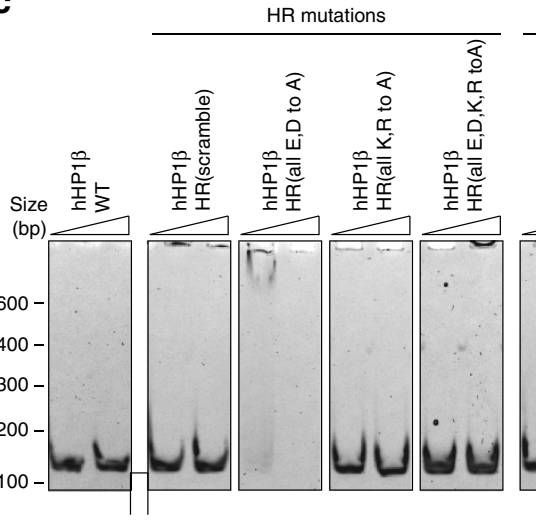

NT mutations

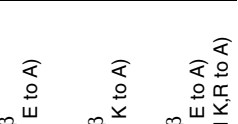
CD exchange

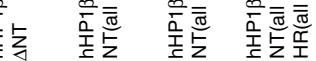

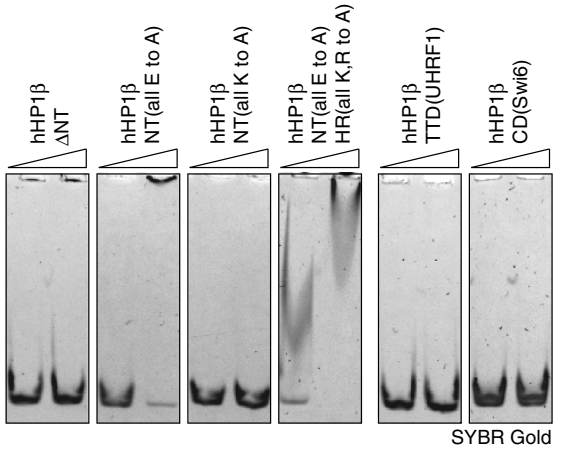

d

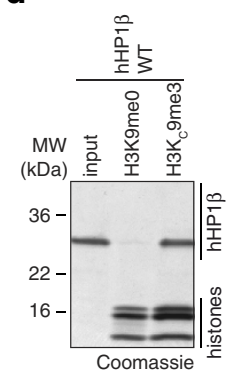

d

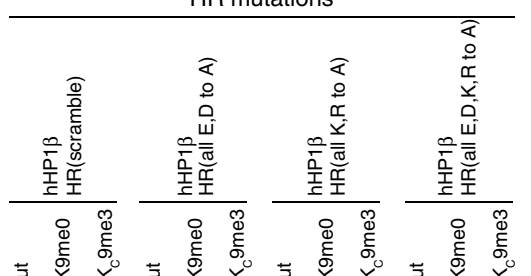

NT mutations

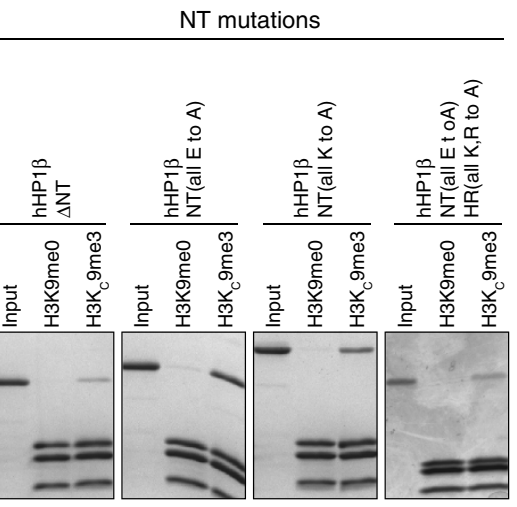

f

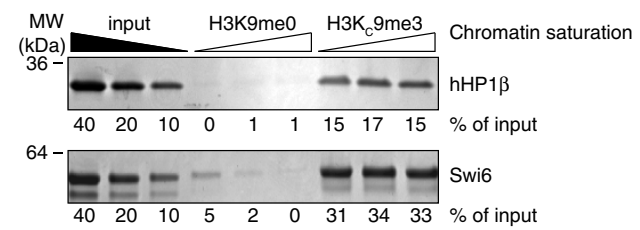

$\mathrm{MW}$
$(\mathrm{kDa})$
$36-$
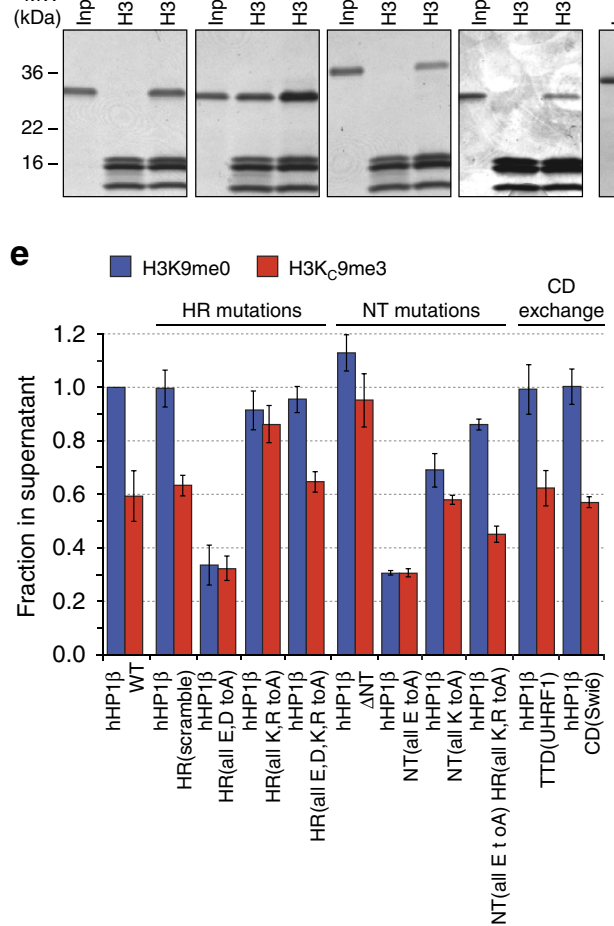
CD exchange

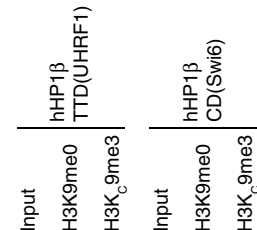


chromatin binding. In agreement with this interpretation, deletion of the HR resulted not only in significant reduction of the chromatin clustering activity of hHP1 $\beta$ but also of the NT, CD(hHP1 $\beta$ )-GST hybrid protein (Supplementary Fig. 7d and e). Furthermore, exchange of the hHP $1 \beta$ HR with the corresponding regions of hHP1 $\alpha$ and Swi6, which contain a surplus of positive charges (Supplementary Fig. 2a and Supplementary Table 2), caused strong DNA binding concomitant with strong chromatin clustering of both, $\mathrm{H} 3 \mathrm{~K} 9 \mathrm{me} 0$ and $\mathrm{H} 3 \mathrm{~K} 9 \mathrm{me} 3$ oligonucleosomes (Supplementary Fig. 7f and g).

The NT region of hHP1 $\beta$ is also highly enriched in charged amino acids (Supplementary Fig. 2a). In agreement with the manifold contacts with the $\mathrm{H} 3$ tail detected in the cross-linking experiments, deletion of this region (hHP1 $\beta \Delta \mathrm{NT}$ ) caused loss of recovery with precipitated $\mathrm{H} 3 \mathrm{~K} 9 \mathrm{me} 3$ chromatin (Fig. $5 \mathrm{~d}$ ) as well as failure of chromatin clustering (Fig. 5e). Mutating the negatively charged residues (hHP1 $\beta$ NT (all E to A)) enhanced DNA binding and resulted in strong, unspecific chromatin clustering. Mutating the positively charged residues (hHP1 $\beta$ NT (all $\mathrm{K}$ to A)) had no effect on DNA binding but caused enhanced chromatin clustering of $\mathrm{H} 3 \mathrm{~K} 9 \mathrm{me} 0$, while the effect on $\mathrm{H} 3 \mathrm{~K} 9 \mathrm{me} 3$ oligonucleosomes was similar to hHP1 $\beta$ WT. Together with the results from the cross-linking, we concluded that the NT of hHP1 $\beta$ balances unspecific binding to DNA and the $\mathrm{H} 3$ tail. Indeed, opposing double mutation of charged residues in the NT and HR regions neutralized each other's chromatin effects (hHP1 $\beta$ NT (all E to A) HR (all K,R to A), Fig. 5d,e).

CD of hHP1ß only functions in mediating H3K9me3 interaction. In contrast to what has been described for Swi6 (ref. 29), we failed to detect any multimerization of hHP1 $\beta$ beyond CSD-mediated dimerization using highly sensitive dynamic light scattering (Supplementary Fig. 8a), SAXS ${ }^{16}$, protein cross-linking (Supplementary Fig. 7a) or nuclear magnetic resonance ${ }^{30}$. Furthermore, SPR experiments similar to those done with Swi6 on $\mathrm{H} 3 \mathrm{~K} 9 \mathrm{me} 3$ peptide and $\mathrm{H} 3 \mathrm{~K} 9 \mathrm{me} 3$ mononucleosomes coated surfaces were fully consistent with a bivalent interaction mode of the hHP1 $\beta$ dimer but did not point to any preformed or induced higher order multimerization of the protein (Supplementary Fig. 8 and Supplementary Note 1).

To address this discrepancy, we compared the chromatin binding and effects of hHP1 $\beta$ and Swi6. hHP1 $\beta$ bound specifically to $\mathrm{H} 3 \mathrm{~K} 9 \mathrm{me} 3$ oligonucleosomes irrespective of the saturation level of the chromatin template with nucleosomes (Fig. 5f and Supplementary Fig. 9a). In contrast, the specificity of Swi6 association with $\mathrm{H} 3 \mathrm{~K} 9 \mathrm{me} 0$ and $\mathrm{H} 3 \mathrm{~K} 9 \mathrm{me} 3$ oligonucleosomes increased significantly when the chromatin was more saturated. This effect is caused by the strong unspecific DNA binding activity of the HR of Swi6 (Supplementary Fig. 9b). Interestingly, we found Swi6 recovered to a higher degree in $\mathrm{H} 3 \mathrm{~K} 9 \mathrm{me} 3$ chromatin coprecipitation compared with hHP1 $\beta$. Quantification deduced a stoichiometry of approximately four Swi6 molecules but only two hHP1 $\beta$ molecules bound per nucleosome under saturating protein concentrations (Fig. 5f and Supplementary Fig. 9c).

While it had been suggested before that CD-CD interactions mediate tetrameric binding of Swi6 on mononucleosomes ${ }^{29}$, this region was clearly not sufficient for the observed effect. A hybrid hHP1 $\beta$ protein where the CD was replaced with that of Swi6 (hHP1 $\beta$ CD(Swi6)) did behave like hHP1 $\beta$ WT, not like Swi6. It also exhibited a chromatin clustering effect equivalent to hHP1 $\beta$ WT (Fig. 5d,e). Obviously, the additional effects of Swi6 must reside in regions outside the $\mathrm{CD}$. We deduced that the only role of the CD in HP1 chromatin binding is indeed in mediating targeting to $\mathrm{H} 3 \mathrm{~K} 9 \mathrm{me} 3$. To further sustain this idea, we replaced the CD of hHP1 $\beta$ with the tandem tudor domain (TTD) of UHRF1, which has been shown to specifically recognize H3K9me3 with micromolar affinity (Supplementary Fig. 7c) ${ }^{31}$. Indeed, the hybrid hHP1 $\beta$ TTD(UHRF1) protein displayed chromatin binding and clustering reminiscent of hHP1 $\beta$ WT (Fig. 5d,e).

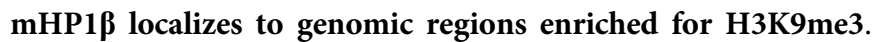
Having established the basic molecular parameters of hHP1 $\beta$ chromatin binding and effects in vitro, we wanted to determine whether these are applicable in a cellular context. Our results predicted that HP1 $\beta$ binds more stably to chromatin areas where the local concentration of $\mathrm{H} 3 \mathrm{~K} 9 \mathrm{me} 3$ is high. In absence of methods to detect three-dimensional enrichment of $\mathrm{H} 3 \mathrm{~K} 9 \mathrm{me} 3$ in defined subnuclear volumes, we looked at the distribution of HP1 $\beta$ along the genome (that is, localization in one dimension). We employed genome-wide binding analysis of HP1 $\beta$ in mouse embryonic stem cells (mESC). The sequences of mouse and human HP1 $\beta$ proteins are identical and mESC with knock out of essential H3K9me3 methyltransferases exist ${ }^{32}$.

Previous genome-wide analysis mainly focused on correlations between $\mathrm{mHP} 1 \alpha$ and $\mathrm{H} 3 \mathrm{~K} 9 \mathrm{me} 3$ at repetitive elements ${ }^{33}$. Given the general high abundance of $\mathrm{H} 3 \mathrm{~K} 9 \mathrm{me} 3$ at these regions ${ }^{34}$, this does not allow obtaining quantitative estimation of HP1 dependency on genome-wide $\mathrm{H} 3 \mathrm{~K} 9$ me 3 levels. To address this, we performed genome-wide antibody-based chromatin immunoprecipitation-sequencing (ChIP-seq) to measure mHP1 $\beta$ binding and compared the results with $\mathrm{H} 3 \mathrm{~K} 9 \mathrm{me} 3$ enrichment previously obtained in the same mESC line ${ }^{35}$. The mouse genome was partitioned into $1 \mathrm{~kb}$-sized tiles, and $\mathrm{mHP} 1 \beta$ and $\mathrm{H} 3 \mathrm{~K} 9 \mathrm{me} 3$ enrichments above input were calculated for each of these tiles. mHP1 $\beta$ and H3K9me3 were found highly correlated along the entire genome (Fig. 6a, Pearson's $R=0.77$ ), and this was also evident at single loci (Fig. 6b). Importantly, an independent data set consisting of green fluorescent protein (GFP)-tagged mHP1 $\beta$ that was generated in a separate mESC line confirmed these findings (Supplementary Fig. 10a and b). Furthermore, by measuring genome-wide changes in $\mathrm{H} 3 \mathrm{~K} 9 \mathrm{me} 3$ after conditional SETDB1 deletion ${ }^{36}$, we observed that the strongest loss of H3K9me3 occurred at sites enriched for mHP1 $\beta$ in WT cells (Fig. 6c and Supplementary Fig. 10c). This supported our

Figure 5 | Modulation of CD and CSD functions by the HR and NT of hHP1ß. (a) Scheme representing EDC cross-links identified within the $\mathrm{hHP} 1 \beta /{\mathrm{H} 3 \mathrm{~K}_{\mathrm{C}}}$ me3 oligonucleosome complex under conditions of chromatin clustering $\left(13.4 \mathrm{nM} \mathrm{H} 3 \mathrm{~K}_{\mathrm{C}} 9 \mathrm{me} 3\right.$ oligonucleosomal arrays, $15 \mu \mathrm{M}$ hHP1 $\beta_{\text {, }}$ $100 \mathrm{mM} \mathrm{NaCl}$ ) using mass spectrometry. For detailed listing of the crosslinks see Supplementary Data 1. (b) Schematic representation of hHP1 $\beta$ mutant proteins. (c) The indicated recombinant proteins were incubated with a DNA fragment of $150 \mathrm{bp}$ at 500: 1 and 1,500: 1 molar ratio. Complexes were separated by PAGE. DNA was stained with SYBR Gold. (d) Chromatin coprecipitation of the indicated wild-type (WT) and mutant hHP1 $\beta$ proteins with oligonucleosomes. Precipitated material was run on SDS-PAGE and stained with Coomassie blue. Input, 10\%. (e) Chromatin precipitation analysis of oligonucleosomes with hHP1 $\beta$ WT or mutant proteins under non-saturating conditions. DNA remaining in the supernatant after centrifugation was incubated with EtBr and measured by fluorescence reading. Data were normalized to DNA levels present in the H3K9meO chromatin/hHP1 $\beta$ WT sample. Averages of three independent experiments are plotted; error bars represent s.d.; $n=3$. (f) Chromatin coprecipitation of the indicated proteins with oligonucleosomes reconstituted to different saturation (0.8: 1.0, 1.0: 1.0 and 1.0: 1.2 ratio of octamers to positioning sequences). Precipitated material was run on SDS-PAGE and stained with Coomassie blue. Intensity of bands was quantified in relation to the input. Representative experiment is shown. 

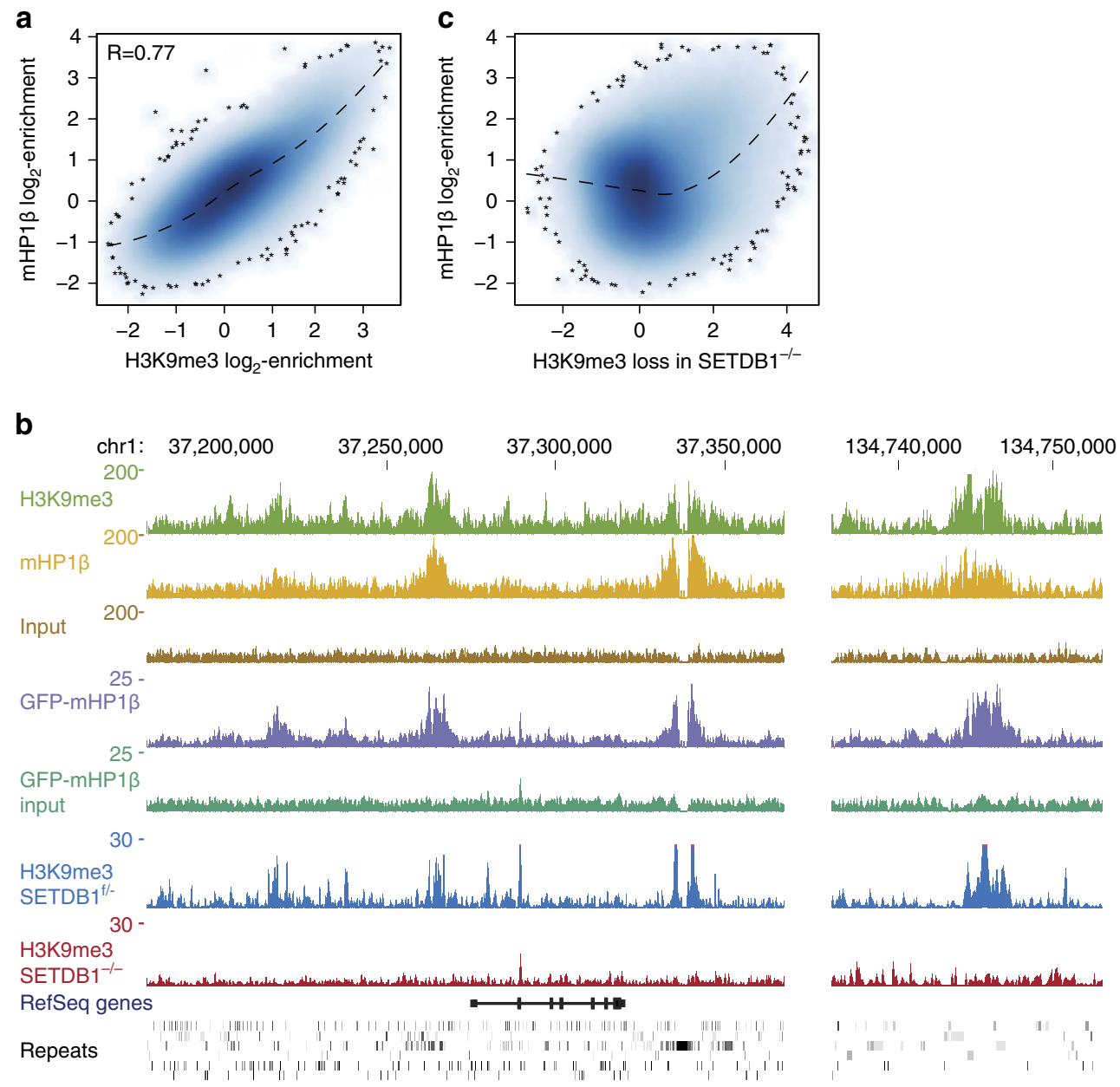

Figure 6 | Genome-wide enrichment of HP1及 correlates with SETDB1-dependent H3K9me3 deposition. (a) Plot of genome-wide correlation of mHP1 $\beta$ and H3K9me3 (ref. 35) as deduced by ChIP-seq in mouse ESC and using $1 \mathrm{~kb}$-sized windows. Dashed line indicates the data trend computed by loss regression. (b) Tracks displaying number of library-normalized reads per $100 \mathrm{bp}$ from the indicated ChIP-seq experiments. Data obtained from antibody-based enrichments of endogenous $\mathrm{mHP1} \beta$ (top) and GFP-tagged mHP1 $\beta$ (middle) and the respective input tracks are shown. H3K9me3 data in $\mathrm{SETDB1}^{\mathrm{f} /-}$ and SETDB1 ${ }^{-/-}$experiments are from ref. 36. Gene models and repetitive elements are indicated at the bottom. (c) Analysis as in a but comparing mHP1 $\beta$ binding to H3K9me3 loss in SETDB1 ${ }^{-/-}$mESC. H3K9me3 loss is shown as the $\log _{2}$-difference between SETDB1 $1^{\mathrm{f} /-}$ and SETDB1 ${ }^{-/-}$.

hypothesis that binding of mHP1 $\beta$ is preferentially targeted to genomic regions with high local concentration of $\mathrm{H} 3 \mathrm{~K} 9 \mathrm{me} 3$.

hHP1及 dimerization maintains compacted chromatin states. To test whether dimerization is essential for the chromatin functions of HP1 $\beta$, we first determined the subnuclear distribution of WT and mutant proteins in mouse fibroblasts. GFP-hHP1 $\beta$ largely localized to characteristic areas of pericentromeric heterochromatin enriched in $\mathrm{H} 3 \mathrm{~K} 9 \mathrm{me} 3$. As deduced from our in vitro observations, the W42A, I161A or isolated $\mathrm{CD}$ mutant proteins, in contrast, showed diffuse distribution. However, heterologous dimerization of the NT-CD-HR via GST (NT, CD, HR(hHP1 $\beta$ )-GST) was sufficient to fully restore heterochromatin localization. In agreement with a contributing role of the HR, the NT, CD(hHP1 $\beta)$-GST hybrid protein, did not completely copy the appearance of the WT factor (Supplementary Fig. 11a and b).

We then adopted a previously described 'chromatin reporter system' that contains repetitive DNA arrays of LacO coupled to a regulatory transcription cassette (Fig. 7a). Integrated into the genome of U2OS cells these can be visualized after expression of mCherry-LacI as singular spot of heterochromatin ${ }^{37,38}$.
Activation of transcription via doxycycline-induced expression of the rtTA activator resulted in decondensation of the array (Fig. 7b, YFP-LacI). Unfolding of the array on such activation was largely reduced by tethering of LacI-YFP-hHP1 $\beta$ WT but not the dimerization deficient I161A mutant to the locus (Fig. 7b,c). As expected, LacI-YFP-hHP1 $\beta$ W42A behaved very similar to the WT protein, as tethering of the exogenous protein to the locus was achieved by the LacI domain independently of $\mathrm{CD} / \mathrm{H} 3 \mathrm{~K} 9 \mathrm{me} 3$ interaction. Nevertheless, heterologous dimerization of the NT-CD-HR region of hHP1 $\beta$ via GST (NT, CD, HR(hHP1 $\beta$ )GST) was sufficient to prevent unfolding of the array on activation. In agreement with contribution of the $H R$, the deletion of this domain resulted in an intermediate effect.

\section{Discussion}

We postulate that hHP1 $\beta$ exemplifies the fundamental interaction mode of HP1 proteins with chromatin. In our model (Fig. 8a,b) dimerization of the chromatin-binding module (that is, NT-CD) is required for increasing the avidity of the interaction by enabling longer residence time of HP1 on chromatin. While the $\mathrm{CD}$ is the main chromatin-binding domain, the charged NT provides additional anchoring via unspecific electrostatic interaction with the H3 tail. Flexibility within the HR allows binding 

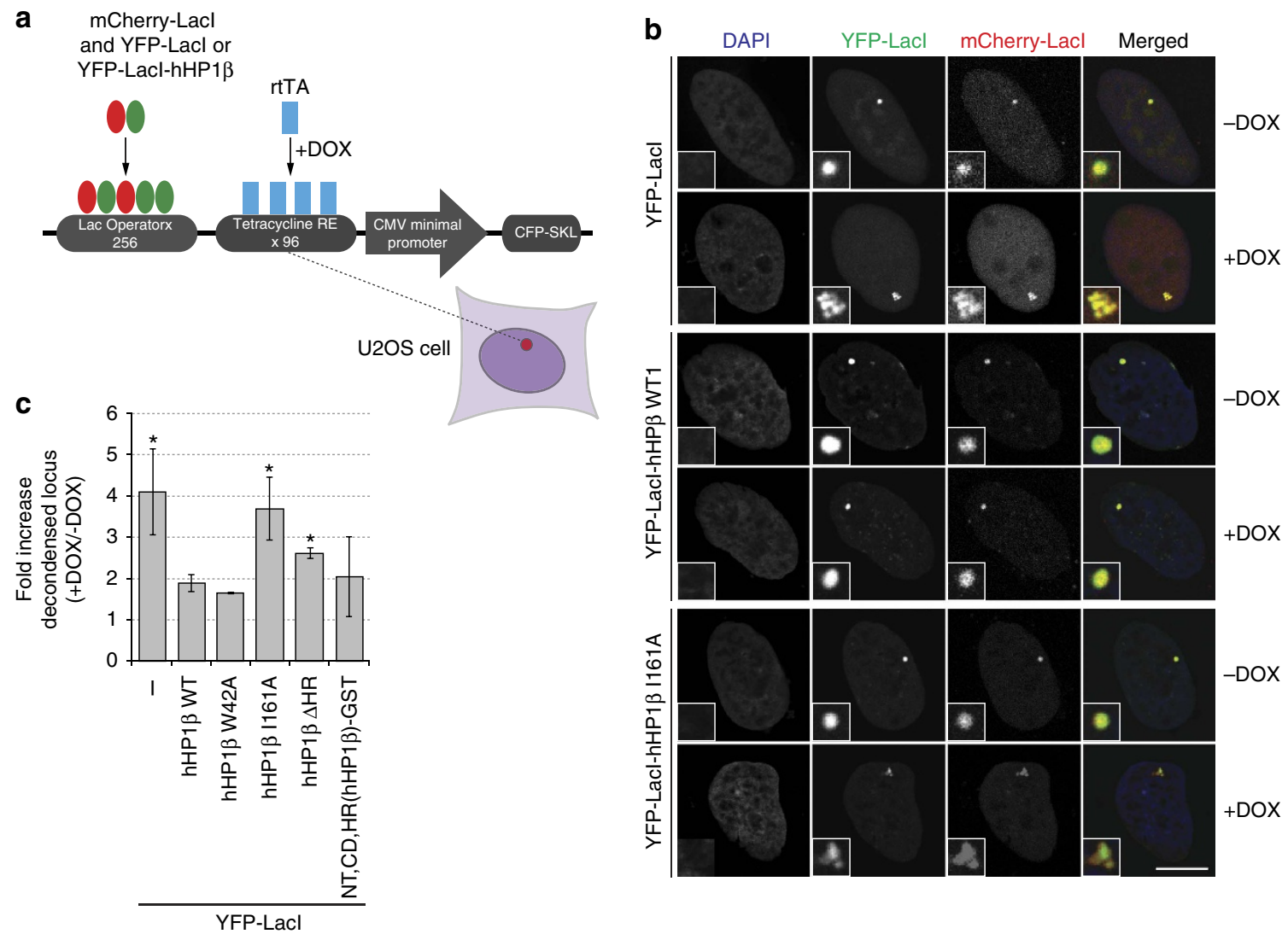

Figure 7 | hHP1及 dimerization is required for maintaining condensed cellular chromatin states. (a) Schematic diagram of the transgene system used to test chromatin compaction effects of hHP1B. A tandem array of the construct has been integrated into the genome of U2OS mammalian cells. Dox, doxycycline; rtTA, reverse tetracycline-controlled TET-VP16 transactivator, whose binding to tetracycline responsive elements (RE) is activated by doxycycline. (b) Together with mCherry-Lacl, the indicated fusion proteins were transiently expressed in U2OS cells containing the chromatin reporter array as described in $\mathbf{a}$. Representative confocal images in the absence or after induction of transcription from the array with doxycycline (Dox) are shown. DNA was stained with DAPI. Inlets show enlarged chromatin reporter array; scale bar, $10 \mu \mathrm{m}$. (c) Quantification of the results shown in $\mathbf{b}$ together with results of similar experiments using additional hHP1 $\beta$ mutant proteins. Averages of three independent experiments are plotted; error bars represent s.d.; $n>300$ for each condition; asterisks represent $P<0.05$ according to Student's $t$-test.

of the chromatin-binding module to two $\mathrm{H} 3$ tails of the same nucleosome and different nucleosomes within the same or distinct chromatin fibres. Since neither the CD within a HP1 dimer nor the $\mathrm{H} 3$ tails are in a fixed orientation, the entropic effect of bivalent interaction onto binding strength is relatively mild (Table 1). Altogether these parameters result in highly dynamic and reversible interaction of $\mathrm{HP} 1$ with $\mathrm{H} 3 \mathrm{~K} 9 \mathrm{me} 3$ chromatin that is in agreement with the structural parameters deduced for hHP1 $\beta$ binding to mononucleosomes ${ }^{30}$, recent single-molecule studies on hHP1 $\alpha$ (ref. 14), as well as the highly mobile behaviour of HP1 proteins within heterochromatin of yeast and mammalian cells ${ }^{39-41}$.

In our model, modulation of the general chromatin-binding mode is brought about by varying sequences in the HR and NT domains as well as possibly their post-translational modification in other HP1 proteins (different variants, different species). We think that within these regions the overall charge but not a particular sequence is mainly dictating the chromatin-binding properties. Consistent with the requirement of a spacing and flexible linker (Fig. 8a), these domains are of relative low-sequence conservation and of varying length in different HP1 proteins (for example, HR(hHP1 $\gamma$ ), 30 aa; HR(Swi6), 120 aa). In hHP $1 \alpha$ the HR contains a surplus in positively charged residues (Supplementary Fig. 2a). Consequently, the protein shows limited discrimination between $\mathrm{H} 3 \mathrm{~K} 9 \mathrm{me} 0$ and $\mathrm{H} 3 \mathrm{~K} 9 \mathrm{me} 3$ chromatin due to $\mathrm{CD}$-independent binding of $\mathrm{DNA}^{12}$. Phosphorylation of the
NT neutralizes the surplus of positive charges and thereby directs an $\mathrm{H} 3 \mathrm{~K} 9 \mathrm{me} 3$-specific chromatin-binding mode ${ }^{13}$. Interestingly, the NT and HR of hHP1 $\alpha$ but not of hHP1 $\beta$ are extensively post-translationally modified ${ }^{42}$.

Swi6 contains an even more positively charged HR, which causes more pronounced binding to unmodified chromatin ${ }^{29}$, as well as an unusual long NT (Supplementary Fig. 2a). The superstoichometric recruitment of Swi6 to H3K9me3 chromatin observed by others ${ }^{29}$ and us has been attributed to ordered oligomerization of the protein via additional, induced CD-CD interaction $^{43}$. However, we find that the Swi6(CD) is not sufficient for this effect (Fig. 5d,e). Contrariwise, our studies on hHP1 $\beta$ and work on hHP1 $\alpha$ (ref. 14) clearly show that these proteins do not multimerize beyond dimerization in chromatin binding. Also, recent modelling approaches deduced an allosterically controlled mode of Swi6 in the absence of CD-CD interaction ${ }^{4}$. While the functional differences between Swi6 and mammalian HP1 proteins need to be further investigated, we note that this new interpretation of previous data is fully compatible with our general model.

How does the flexible and dynamic binding mediate the chromatin clustering effects of hHP1 $\beta$ We think the protein stabilizes condensed structures rather than inducing these de novo. It does not work as a locally directed and static chromatin clamp as suggested on the basis of the alleged binding mode of Swi6 (refs 45,46). Yet, via a large number of transient 
a

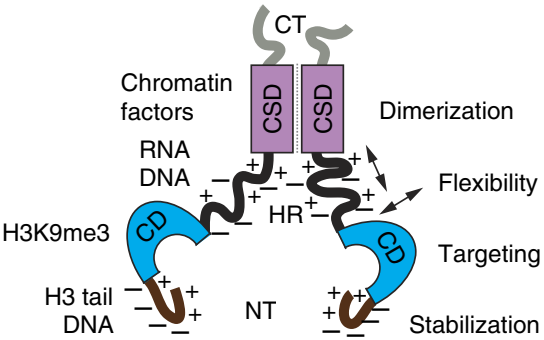

b

Low density of H3K9me3: rapid on-off

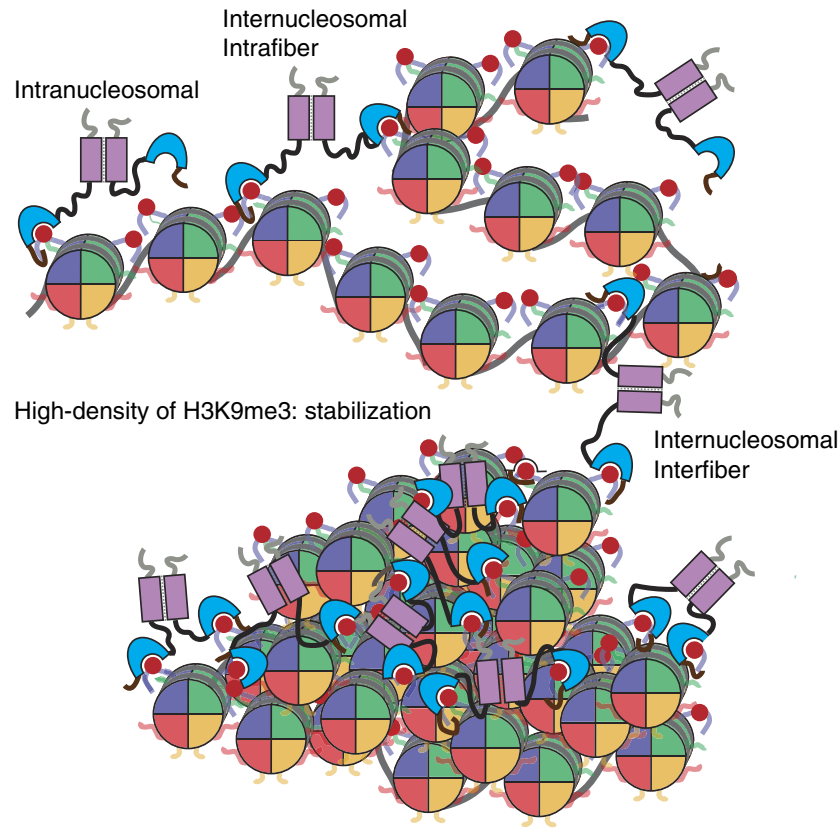

Figure 8 | hHP1及 is a paradigm HP1 protein. (a) Model summarizing the functional properties (right) and interactions of different domains of hHP1 The balance of negatively and positively charged residues within the NT and $\mathrm{HR}$ is essential for specific H3K9me3-chromatin interaction. (b) Due to its flexible HR the CD of an hHP1 $\beta$ dimer can interact with the H3K9me3 marks of the same or different nucleosomes within the same or another chromatin fibre (top). The binding is stabilized by flexible and dynamic electrostatic interaction of the NT with the $\mathrm{H} 3$ tail. The high concentration of H3K9me3 in condensed and clustered oligonucleosomes (bottom) establishes multiple hHP1 $\beta$ binding possibilities. This steadies the interaction and stabilizes the compacted chromatin state.

and unordered bridging events HP1 keeps chromatin fibres associated in a plastic manner (Fig. 8b). First, local high concentration of $\mathrm{H} 3 \mathrm{~K} 9 \mathrm{me} 3$, which is found in compacted chromatin regions, is required for stable hHP1 $\alpha$ (ref. 14) and hHP1 $\beta$ (our work) chromatin association. Second, the main effect of HP1 dimerization and locally enriched $\mathrm{H} 3 \mathrm{~K} 9 \mathrm{me} 3$ is in reducing the off-rate of the protein from chromatin (Fig. 2d, ref. 14). Third, HP1 is not able to induce chromatin clustering in absence of the $\mathrm{H} 4$ tail, which is important in higher order chromatin folding ${ }^{23}$. Bridging of $\mathrm{H} 3$ tails is either not possible in a relaxed chromatin state or is not sufficient for inducing chromatin compaction. We think that conformational fluctuations in chromatin fibres that allow transient local folding and unfolding are trapped by HP1 when yielding patches with high concentration of $\mathrm{H} 3 \mathrm{~K} 9 \mathrm{me} 3$.

A major consequence of our interpretation is that cellular HP1-localization, -dynamics and -working mode are directed by the local density of $\mathrm{H} 3 \mathrm{~K} 9 \mathrm{me} 3$, which might help explain the diverse biology ascribed to these proteins in hetero- and euchromatin ${ }^{10,47,48}$. For example, an intimate relationship exists between heterochromatin and the nuclear periphery in various metazoans ${ }^{49}$. H3K9 methylation appears to be the major driving force for the localization of genomic regions to the nuclear periphery and these generally overlap with lamina-associated domains ${ }^{50}$. Although a direct involvement in the recruitment to the nuclear periphery is controversial, the very dense chromatin areas might be clustered and stabilized by HP1. We think the dynamic mode of HP1 binding and actions on H3K9me3 chromatin allows flexible clustering and re-clustering of different regions of chromatin within the same or distinct chromosomes thereby contributing to the establishment and maintenance of heterochromatin. Importantly, such working mechanism is in agreement with an emerging view of high plasticity of nuclear chromatin in the absence of hierarchical organization $^{51-53}$.

\section{Methods}

Plasmids. Plasmids containing DNA templates for chromatin reconstitution were a gift of Dr Daniela Rhodes (MRC Cambridge, UK). Plasmids for expression of recombinant histones from Xenopus laevis were a gift from Dr. Karolin Luger (University of Colorado, Boulder). Complementary DNAs (cDNAs) corresponding to hHP1 $\beta$ (GenBank NM_001127228) were amplified by PCR using a $5^{\prime}$ primer that introduces a $\mathrm{His}_{6}$ affinity tag and cloned into pET11a expression vector. Alternatively, the hHP1 $\alpha($ GenBank BC006821) and hHP1 $\beta$ cDNAs were cloned into pCold I (Takara Bio/Clontech, Saint-Germain-en-Laye, France). For point and deletion mutants, site-directed mutagenesis was carried out using the Stratagene QuickChange protocol or a Q5 site-directed mutagenesis kit (New England Biolab, Frankfurt, Germany) according to the manufacturers' instruction. cDNAs for other chimeric proteins were synthesized by Genewiz (South Plainfield, USA). YFP-LacI-NSL C1 and YFP-LacI C1 expression vectors were kind gifts from Dr Supriya Prasanth (University of Illinois, IL, USA) ${ }^{38}$. hHP1 $\beta$ WT, mutant and chimera cDNAs were amplified from the bacterial expression vectors by PCR and cloned into SalI-BamHI sites of the YFP-LacI C1 vector. A detailed list of the plasmids used in this study can be found in Supplementary Table 3.

Western blotting. Anti-histone H3 (1/10,000; ab1791, Abcam, Cambridge, UK), swine anti-rabbit IgG (1/2500; P0399; DAKO, Hamburg, Germany), anti-His ${ }_{6}$-peroxidase $(1 / 500 ; 1965085001$; Roche, Mannheim, Germany); anti-hHP1 $\beta$ (1:2000; MAB3448, Merck Millipore, Schwalbach, Germany). Uncropped scans of gels and blots are provided in Supplementary Fig. 12.

Expression and purification of recombinant HP1 proteins. For pET11a vectors, proteins were expressed using ZYM-5052 auto-inducing medium overnight at $30^{\circ} \mathrm{C}$. For pColdI vectors, proteins were expressed in the same cells using standard $\mathrm{LB}$ medium overnight at $15^{\circ} \mathrm{C}$ in the presence of $0.4 \mathrm{mM}$ IPTG. For production of pBpa-containing hHP1 $\beta$, His-tagged hHP1 $\beta$ (N57X, Q158X) was expressed in the presence of pSUP-BPARS ${ }^{54}$ in E. coli BL21 DE3 in standard LB medium supplemented with $2 \mathrm{mM}$ pBPA. Protein expression was induced at $\mathrm{OD}_{600 \mathrm{~nm}}=1$ by the addition of $1 \mathrm{mM}$ IPTG for $4 \mathrm{~h}$. All proteins were purified on Ni-NTA beads (Qiagen, Hilden, Germany) using standard protocols followed by anion exchange chromatography (MonoQ, GE Healthcare, Freiburg, Germany). Alternatively, proteins were purified using His-Pur Cobalt resin (Thermo Scientific,

Braunschweig, Germany) with several rounds of high-salt washes $(0.8 \mathrm{M} \mathrm{NaCl})$ before elution. Purified proteins were dialyzed against PBS, $10 \%(\mathrm{v} / \mathrm{v})$ glycerol, $2 \mathrm{mM}$ DTT or a buffer containing $10 \mathrm{mM}$ triethanolamine (pH 7.5), $150 \mathrm{mM} \mathrm{NaCl}$, $1 \mathrm{mM}$ DTT $30 \%(\mathrm{v} / \mathrm{v})$ glycerol. Aliquots of purified protein were stored at -80 or $-20^{\circ} \mathrm{C}$, respectively.

Expression and purification of recombinant histones. Core histones were expressed in E. coli BL21 (DE3) RIL cells using ZYM-5052 auto-inducing medium. Histone proteins were found exclusively in inclusion bodies, which were solubilized in unfolding buffer $(7 \mathrm{M}$ deionized urea, $20 \mathrm{mM}$ Tris- $\mathrm{HCl}$ ( $\mathrm{pH}$ 7.5), $10 \mathrm{mM}$ DTT). The material was dialyzed against urea chromatography buffer ( $7 \mathrm{M}$ deionized urea, $10 \mathrm{mM}$ Tris- $\mathrm{HCl}(\mathrm{pH} 7.5), 1 \mathrm{mM}$ EDTA, $100 \mathrm{mM}$ $\mathrm{NaCl}, 2 \mathrm{mM}$ DTT, 0.2 mM PMSF) and loaded onto a Q Sepharose column in front of a SP Sepharose column (both GE Healthcare, Freiburg Germany). After washing with five column volumes of urea chromatography buffer, the Q Sepahraose column with bound DNA and contaminating proteins was removed. Histone proteins were eluted from the SP Sepharose column using a linear gradient from 0.1 to $0.6 \mathrm{M} \mathrm{NaCl}$. Purified histones were dialyzed extensively against $\mathrm{dd}_{2} \mathrm{O}$, lyophilized and stored at $-80^{\circ} \mathrm{C}$. 
Native chemical ligation. $0.2 \mathrm{mM}$ of $\mathrm{H} 3 \Delta 1-20$, A21C and $1 \mathrm{mM}$ of $\mathrm{N}$-terminal $\mathrm{H} 3$ peptide (1-20) with a C-terminal thioester group were ligated for $24 \mathrm{~h}$ in $100 \mathrm{mM}$ potassium phosphate, $3 \mathrm{M}$ guanidine- $\mathrm{HCl}, 0.5 \%(\mathrm{v} / \mathrm{v})$ benzyl mercaptan, $0.5 \%(\mathrm{v} / \mathrm{v})$ thiophenol, $\mathrm{pH} 7.9$ at $25^{\circ} \mathrm{C}$ with vigorous mixing. The crude reaction mixture was dissolved into 25:75:0.1 acetonitrile/water/trifluoroacetic acid, diluted fivefold into SAU-200 buffer ( $7 \mathrm{M}$ deionized urea, $20 \mathrm{mM}$ sodium acetate ( $\mathrm{pH} 5.2), 1 \mathrm{mM}$ EDTA, $1 \mathrm{mM}$ DTT, $200 \mathrm{mM} \mathrm{NaCl}$ ), applied to a Hi-Trap SP-Sepharose highperformance cation exchange column (GE Healthcare, Freiburg, Germany), and eluted with a linear $\mathrm{NaCl}$ gradient from 200 to $600 \mathrm{mM}$. Protein samples were dialyzed extensively against $2 \mathrm{mM}$ DTT at $4^{\circ} \mathrm{C}$, lyophilized and stored at $-80^{\circ} \mathrm{C}$.

Site-specific installation of $\mathbf{H 3 K}_{\mathbf{c}} \mathbf{9 m e} \mathbf{3}$. H3K9C, C110A was expressed and purified as WT histones. $5 \mathrm{mM}$ of mutant $\mathrm{H} 3$ was reduced for $1 \mathrm{~h}$ at $37^{\circ} \mathrm{C}$ in alkylation buffer (1 M HEPES, $4 \mathrm{M}$ guanidium- $\mathrm{HCl}, 10 \mathrm{mM} \mathrm{D} / \mathrm{L}-m e t h i o n i n e$, $20 \mathrm{mM}$ DTT, $\mathrm{pH}$ 7.8). Alkylation reactions were performed at $50^{\circ} \mathrm{C}$ in the presence of $400 \mathrm{mM}$ (2-bromoethyl)-trimethylammonium bromide (Sigma-Aldrich, Steinheim, Germany) in the dark with occasional mixing. After $2.5 \mathrm{~h}$ of incubation, $10 \mathrm{mM}$ of fresh DTT was added and the reaction was allowed to proceed for another $2.5 \mathrm{~h}$ at $50^{\circ} \mathrm{C}$. The alkylation reaction was quenched with $700 \mathrm{mM}$ 2 -mercaptoethanol, and the crude reaction mixture was diluted 50 -fold into SAU-200 buffer. Alkylated histones were purified by anion exchange chromatography as described above.

Reconstitution of histone octamers. Lyophilized purified WT core histones $\mathrm{H} 2 \mathrm{~A}, \mathrm{H} 2 \mathrm{~B}, \mathrm{H} 4$ and WT or modified $\mathrm{H} 3$ were dissolved in unfolding buffer and mixed to equimolar ratios. The histone mixture was extensively dialyzed at $4^{\circ} \mathrm{C}$ against RB high buffer (10 mM Tris-HCl, $1 \mathrm{mM}$ EDTA, $2 \mathrm{M} \mathrm{NaCl}, 1 \mathrm{mM}$ DTT, $\mathrm{pH}$ 7.5) with at least three changes of dialysis buffer. Histone octamers were concentrated to $10-20 \mathrm{mg} \mathrm{ml}^{-1}$ using Amicon Ultra centrifugal filter units (Millipore, Billerica, USA) and purified on a HiLoad 16/60 Superdex 200 prep grade gel filtration column (GE Healthcare, Freiburg, Germany). Peak fractions were pooled and concentrated to at least $2 \mathrm{mg} \mathrm{ml}^{-1}$. Histone octamers were stored in $50 \%(\mathrm{v} / \mathrm{v})$ glycerol at $-20^{\circ} \mathrm{C}$.

Reconstitution of chromatin templates. Mononucleosomes were reconstituted on a 187 bp DNA fragment containing the '601' sequence flanked on each site by a linker of $20 \mathrm{bp}^{55}$. Oligonucleosomes were reconstituted on a $12 \times 200 \mathrm{bp} \times 601$ template ${ }^{56}$. Plasmids carrying the respective inserts were purified using a Giga kit (Qiagen, Hilden, Germany). Templates for reconstitution were released from plasmids by restriction digest with $B s o \mathrm{BI}$ for mononucleosomes and a mix of DdeI, $B f u C I, H a e I I$ and EcoRI for oligonucleosomes. To separate vector backbone from DNA used for chromatin assembly stepwise precipitation with polyethylene glycol (PEG) $6000 / 0.5 \mathrm{M} \mathrm{NaCl}$ was carried out (final PEG concentration 2-9\% and $20 \%$ $(\mathrm{w} / \mathrm{v}))$. DNA pellets were washed with $70 \%(\mathrm{v} / \mathrm{v})$ ethanol and dissolved in water. Double stranded, short, biotinylated DNA linkers were ligated to the DNA template before

chromatin reconstitution.

Histone octamers were dialyzed for at least $3 \mathrm{~h}$ against RB high buffer. DNA templates were added in a molar ratio of 0.8-1.2 (concentration of nucleosome positioning sites to histone octamers). The reaction mixtures were dialyzed against RB high buffer that was continuously replaced by RB low buffer $(10 \mathrm{mM}$ Tris- $\mathrm{HCl}$, $1 \mathrm{mM}$ EDTA, $10 \mathrm{mM} \mathrm{NaCl}, 1 \mathrm{mM}$ DTT, pH 7.5) over a $36 \mathrm{~h}$ period using a peristaltic pump. Quality and nucleosome saturation of reconstitution reactions were monitored by agarose gel electrophoresis and analytical ultracentrifugation. Reconstituted chromatin templates were extensively dialyzed against TEAE buffer (10 mM triethanolamine $\mathrm{HCl} \mathrm{pH} \mathrm{7.5,} \mathrm{0.1} \mathrm{mM} \mathrm{EDTA,} \mathrm{pH} \mathrm{7.5)} \mathrm{and} \mathrm{stored} \mathrm{at} 4^{\circ} \mathrm{C}$.

Electrophoretic mobility shift assay. $50 \mathrm{ng} 150 \mathrm{bp}$ DNA amplified from the backbone of pUC18 was incubated with $0,3,9 \mu \mathrm{M}$ recombinant protein in $10 \mu \mathrm{l}$ EMSA buffer (10 mM Tris- $\mathrm{HCl}(\mathrm{pH} 8.0), 100 \mathrm{mM} \mathrm{NaCl}, 5 \mathrm{mM} \mathrm{MgCl}_{2}$ ) for $20 \mathrm{~min}$ at room temperature (RT). $2 \mu \mathrm{l} 50 \%(\mathrm{v} / \mathrm{v})$ glycerol was added and samples were loaded onto 6\% native PAGE gels. After electrophoresis, DNA was visualized by staining with $1 \times$ SYBR Gold/0.25 $\times$ TBE for $20 \mathrm{~min}$ at RT. Images were captured using a ChemiDoc MP Imaging System (Bio-Rad, München, Germany).

Chromatin coprecipitation. $6.7 \mathrm{nM}$ oligonucleosomes were incubated with $1 \mu \mathrm{M}$ recombinant protein in $100 \mu \mathrm{l}$ binding buffer $(10 \mathrm{mM}$ triethanolamine ( $\mathrm{pH} 7.5)$, $150 \mathrm{mM} \mathrm{NaCl}, 5 \mathrm{mM} \mathrm{MgCl} 2,0.1 \mathrm{mM}$ EDTA, $0.1 \%$ (v/v) Triton-X100) for $1 \mathrm{~h}$ on ice. Precipitated chromatin complexes were recovered by centrifugation at $16,100 \mathrm{~g}$ for $30 \mathrm{~min}$ at $4^{\circ} \mathrm{C}$. Pellets were washed once with $0.5 \mathrm{ml}$ binding buffer and centrifuged for $15 \mathrm{~min}$ at $4{ }^{\circ} \mathrm{C}$. Precipitated material was resuspended in $10 \mu \mathrm{l}$ $1 \times$ SDS loading buffer and boiled for $5 \mathrm{~min}$ before running on SDS-PAGE.

Chromatin sedimentation. For saturating conditions, $2.7 \mathrm{nM}$ oligonucleosomes were incubated with $5 \mu \mathrm{M}$ hHP1 $\beta$ proteins in $100 \mu$ l sedimentation buffer $(10 \mathrm{mM}$ triethanolamine ( $\mathrm{pH} 7.5), 150 \mathrm{mM} \mathrm{NaCl}, 0.1 \mathrm{mM}$ EDTA) for $1 \mathrm{~h}$ on ice. For non-saturating conditions, $3 \mu \mathrm{M}$ recombinant proteins were used and the $\mathrm{NaCl}$ concentration in the sedimentation buffer was lowered to $100 \mathrm{mM}$. After incubation, $40 \mu \mathrm{l}$ per sample was placed into a well of a 96-well plate and kept as 'input'. The rest was centrifuged at $16,100 \mathrm{~g}$ for $30 \mathrm{~min}$ at $4^{\circ} \mathrm{C}$. $40 \mu \mathrm{l}$ supernatant was carefully removed and placed into a 96-well plate ('output'). For quantification of chromatin DNA, the input and output samples were incubated with $40 \mu \mathrm{l}$ $0.5 \mu \mathrm{g} \mathrm{ml}^{-1}$ ethidium bromide and fluorescence was measured on a Plate CHAMELEON II fluorescence plate reader (Hidex, Turku, Finland) using a $360 \mathrm{~nm}$ $( \pm 5 \mathrm{~nm})$ excitation filter and a $612 \mathrm{~nm}( \pm 5 \mathrm{~nm})$ emission filter. For each sample the ratio of DNA concentrations after and before centrifugation (output/input) was calculated.

Pull-down experiments. $4 \mu \mathrm{g}$ C-terminally biotinylated histone $\mathrm{H} 3$ peptides (aa 1-20) or $1 \mu \mathrm{g}$ of biotinylated nucleosomes or oligonucleosomal arrays were incubated with $40 \mu \mathrm{l}$ Streptavidin MagnaSphere Paramagmetic beads (Promega, Mannheim, Germany) in $350 \mu \mathrm{l}$ binding buffer (10 mM triethanolamine ( $\mathrm{pH} 7.5)$, $150 \mathrm{mM} \mathrm{NaCl}, 0.1 \mathrm{mM}$ EDTA, $0.1 \%$ (v/v) Triton-X100) supplemented with $1 \mathrm{mg} \mathrm{ml}{ }^{-1}$ BSA for $2.5 \mathrm{~h}$ at RT. Unbound material was removed by three washes with $0.5 \mathrm{ml}$ binding buffer. Charged beads were then incubated with $100 \mathrm{pmol}$ recombinant protein in $350 \mu \mathrm{l}$ binding buffer for $1 \mathrm{~h}$ at $4^{\circ} \mathrm{C}$ on a rotator. Beads were washed three times with $0.5 \mathrm{ml}$ binding buffer for $3 \mathrm{~min}$ per wash at $4^{\circ} \mathrm{C}$. Bound proteins were eluted in $20 \mu \mathrm{l} 1 \times$ SDS loading buffer and by boiling for $5 \mathrm{~min}$.

Fluorescence correlation spectroscopy. All fluorescence measurements were performed with a pulsed custom-built mode-locked Ti:Sa-Laser and a confocal two-photon fluorescence microscope setup. Detailed description of the experimental setup and the measurement procedure are available on request. In all cases $10 \mathrm{nM}$ of the acceptor labelled species, ATTO 610-labelled nucleosomal array, was incubated with $20-200 \mu \mathrm{M}$ of recombinant hHP $1 \beta$ in $10 \mu \mathrm{l}$ of $10 \mathrm{mM}$ triethanolamine $\mathrm{HCl}(\mathrm{pH} 7.5), 0.1 \mathrm{mM}$ EDTA, $150 \mathrm{mM} \mathrm{NaCl}$ at $4^{\circ} \mathrm{C}$. For each sample the fluorescence correlation curve, fluorescence intensity and anisotropy values were determined at $22^{\circ} \mathrm{C}$. Every data point was averaged over a minimum of 15 single measurements of $10 \mathrm{~s}$ each. Excitation was by two-photon mode.

The fluorescence data were analysed using the correlation function $G(\tau)=\frac{I(t) \cdot I(t+\tau)}{I(t)^{2}}-1$, and the equation for free diffusion of particles $G(\tau)=N^{-1} \cdot\left(1+\frac{\tau}{\tau_{D}}\right)^{-1} \cdot\left(1+r_{0}^{2} \frac{\tau}{\tau_{D}}\right)^{-0.5}$, where $\mathrm{I}(t)$ is the fluorescence intensity measured at time $t, N$ the particle number, $\tau_{D}$ the diffusion time, and $r_{0}=0.25$ the axis ratio of the focal region, considering the dimensions of a Gaussian beam waist.

Fluorescence polarization measurements. Experiments were performed in $10 \mathrm{mM}$ triethanolamine $\mathrm{HCl}(\mathrm{pH} 7.4), 150 \mathrm{mM} \mathrm{NaCl}, 0.1 \mathrm{mM}$ EDTA, $2 \mathrm{mM}$ DTT. Titration series of $10 \mu \mathrm{l}$ volume in 384-well plates were read multiple times on a Plate CHAMELEON II plate reader (HIDEX Oy, Turku, Finland). Multiple readings and independent titration series were averaged after data normalization ${ }^{57}$

Isothermal calorimetry. ITC measurements were performed on a iTC200 calorimeter (Microcal, Malvern, UK) at $25^{\circ} \mathrm{C}$ in binding buffer $(10 \mathrm{mM}$ triethanolamine ( $\mathrm{pH} 7.5), 20$ or $150 \mathrm{mM} \mathrm{NaCl}, 0.1 \mathrm{mM}$ EDTA). Reaction heats were recorded by sequences of 37 injections of $1.8 \mathrm{mM} \mathrm{hHP} 1 \beta$, spaced at $120 \mathrm{~s}$ intervals, into $250 \mu \mathrm{l}$ of $60 \mu \mathrm{M} \mathrm{H} 3$ peptides, nucleosomes or oligonucleosomal arrays under constant stirring at 1,000 r.p.m. (injection \#1-10: $0.5 \mu \mathrm{l}$ each; injection \#11-32: $1 \mu \mathrm{l}$ each; injection \#33-37: $2 \mu \mathrm{l}$ each). Heats of dilution, obtained by the titration of hHP1 $\beta$ into buffer, were substracted from raw data before analysis. Raw data were integrated, normalized and the apparent heat change $(\Delta q)$ of the reaction was plotted against the molecular ratio using the Origin software. For the determination of apparent enthalpy changes $\left(\Delta \mathrm{H}_{\text {app }}\right)$, the molar association constant $\left(K_{A}\right)$, and the stoichiometry $(n)$ of the interaction, non-linear least-square fitting of the $\Delta q$ values was performed by the Origin software using a binding model of one set of identical binding sites.

Surface plasmon resonance. SPR measurements were performed on a Biacore 2000 instrument (GE Healthcare, Buckinghamshire, UK) at $298 \mathrm{~K}$ in $10 \mathrm{mM}$ triethanolamine (pH 7.5), $150 \mathrm{mM} \mathrm{NaCl}, 0.1 \mathrm{mM}$ EDTA, $1 \mathrm{mM} \mathrm{DTT}, 0.005 \%$ (v/v) Tween-20. Biotinylated ligands were immobilized on streptavidin-coated sensor chips SA (GE Healthcare, Buckinghamshire, UK). Before immobilization, sensor chips were conditioned as described by the manufacturer. To obtain low surface densities (5-24 RU), $5 \mathrm{nM}$ biotinylated $\mathrm{H} 3$ peptide was injected at a low rate of $10 \mu \mathrm{min}^{-1}$ using varying contact times. High surface densities ( $>700 \mathrm{RU}$ ) were prepared by injecting $3.5 \mathrm{mM}$ peptide $\left(10 \mu 1 \mathrm{~min}^{-1}\right)$ until the SA surface was saturated. Peptide-containing chips were regenerated by applying three short pulses of $0.05 \%(\mathrm{w} / \mathrm{v})$ SDS followed by an injection of $1.5 \mathrm{M} \mathrm{NaCl}$ for baseline stabilization. For binding assays, hHP1 $\beta$ proteins were injected at $24-50 \mu \mathrm{M}$ (serial twofold dilutions) for $2 \mathrm{~min}(30 \mu \mathrm{l} / \mathrm{min}$ ). Dissociation was recorded for up to $5 \mathrm{~min}$. A streptavidin surface without ligands served as reference. In addition, blank runs were performed for double referencing. Data evaluation was performed by steady-state analysis assuming a Langmuir 1:1 binding model using BIAevaluation 4.1 and Prism 5.04 (GraphPad, CA, USA) software. Binding to the unmodified 
peptides was analysed with maximum binding $\left(\mathrm{RU}_{\max }\right)$ set to the corresponding values obtained with the modified peptides.

Scanning force microscopy. Nucleosomal arrays and recombinant hHP1 $\beta$ were dialyzed against SFM buffer ( $5 \mathrm{mM}$ triethanolamine (pH7.5), $50 \mathrm{mM} \mathrm{NaCl}, 0.1 \mathrm{mM}$ EDTA). The recombinant proteins at different concentrations (between 0 and $5 \mu \mathrm{M})$ were preincubated with oligonucleosomes at a DNA concentration of $50 \mathrm{ng} \mathrm{ml}^{-1}$ in SFM buffer for $1 \mathrm{~h}$ at $4^{\circ} \mathrm{C}$, and the samples were fixed with $0.05 \%(\mathrm{v} /$ v) fresh glutaraldehyde (Electron Microscopy Sciences, PA, USA) at $4^{\circ} \mathrm{C}$ overnight. Fixed samples were extensively dialyzed against TEAE buffer $(5 \mathrm{mM}$ triethanolamine (pH 7.5), $0.1 \mathrm{mM}$ EDTA). $10 \mu \mathrm{l}$ of dialyzed sample was deposited on $c a .1 \mathrm{~cm}^{2}$ of freshly cleaved mica (Plano). After 5 min incubation at RT, the mica was washed with $200 \mu \mathrm{l}$ of water (high-performance liquid chromatography grade) and airdried. Images were recorded in air on a Nanoscope V Multi Mode scanning force microscope (Veeco, NY, USA) using an 'E'-scanner with maximum scan size of $15 \times 15 \mu \mathrm{m}$ and silicon-etched probe tips with a typical spring constant of $40 \mathrm{~N} \mathrm{~m}^{-1}$ and a typical resonance frequency of $325 \mathrm{kHz}$ (NSC15, MikroMasch) in tapping mode.

\section{Chemical cross-linking and mass spectrometry. $13.4 \mathrm{nM} \mathrm{H} 3 \mathrm{~K}_{\mathrm{C}} 9 \mathrm{me} 3$} oligonucleosomes were mixed with $2 \mu \mathrm{M}$ hHP1 $\beta$ in $1 \mathrm{ml}$ cross-linking buffer (20 mM sodium phosphate ( $\mathrm{pH} 6.4), 100 \mathrm{mM} \mathrm{NaCl}, 0.1 \%(\mathrm{v} / \mathrm{v})$ Triton-X100) and incubated for $30 \mathrm{~min}$ at RT. Freshly prepared EDC (Sigma-Aldrich, Steinheim, Germany) was added to $15 \mathrm{mM}$ and incubated for $30 \mathrm{~min}$ at RT. In the case of a higher chromatin: hHP $1 \beta$ ratio, $15 \mu \mathrm{M}$ of hHP1 $\beta$ and $35 \mathrm{mM}$ EDC were used. $\mathrm{MgCl}_{2}$ was then added to $5 \mathrm{mM}$ and chromatin and crosslinked/bound hHP1 $\beta$ were recovered by centrifugation at $16,100 \mathrm{~g}$ for $30 \mathrm{~min}$ at $4^{\circ} \mathrm{C}$. The pellet was washed once with the EDC buffer containing $5 \mathrm{mM} \mathrm{MgCl}_{2}$ and dissolved in $20 \mathrm{mM}$ Tris- $\mathrm{HCl}(\mathrm{pH} 8.0), 0.8 \%(\mathrm{w} / \mathrm{v})$ SDS. The sample was denatured for $15 \mathrm{~min}$ at $70^{\circ} \mathrm{C}$, then treated with $20 \mathrm{mM}$ DTT (Merck, Mannheim, Germany) for $30 \mathrm{~min}$ at $56^{\circ} \mathrm{C}$, which was followed by treatment with $20 \mathrm{mM}$ iodoacetamide for $20 \mathrm{~min}$ at RT (Sigma-Aldrich, Steinheim, Germany). The SDS concentration of the sample was adjusted to $\leq 0.1 \%(\mathrm{w} / \mathrm{v})$ and $3 \mu \mathrm{g}$ trypsin (Promega, Mannheim, Germany) was added for $16 \mathrm{~h}$ at $37^{\circ} \mathrm{C}$. Tryptic peptides were purified using Sep-Pak SPE C18 cartages (Waters, Dublin, Ireland) and separated using size-exclusion chromatography ${ }^{58,59}$. Each peptide-containing fraction was analysed on an LTQ-Orbitrap Velos mass spectrometer (Thermo Fisher Scientific, Bremen, Germany $)^{60}$. Data analysis was performed using pLink $^{61}$. All cross-link-containing peptide fragment spectra were manually evaluated ${ }^{62}$. Crosslinks were visualized with xiNET (http://crosslinkviewer.org).

Ultraviolet-mediated protein-protein cross-linking. $54 \mathrm{nM}$ oligonucleosomal arrays were incubated with $8 \mu \mathrm{M}$ standard or photo crosslinkable hHP1 $\beta$ in $100 \mu \mathrm{l}$ binding buffer (10 mM triethanolamine ( $\mathrm{pH} 7.5), 150 \mathrm{mM} \mathrm{NaCl}, 0.1 \mathrm{mM}$ EDTA, $0.1 \%(\mathrm{v} / \mathrm{v})$ Triton-X100) for $30 \mathrm{~min}$ on ice. The mixtures were placed into wells of a custom-made metal sample holder on ice and irradiated with ultraviolet light (365 nm, $8 \mathrm{~W}$ lamps (Vilber Lourmat, Eberhardzell, Germany); the distance between the light source and sample was set $\sim 5 \mathrm{~cm}$ ) for $3 \times 10 \mathrm{~min}$ with intermittent mixing. After irradiation, the samples were collected into $1.5 \mathrm{ml}$ lowbinding tubes (Eppendorf, Hamburg, Germany). $\mathrm{MgCl}_{2}$ was added to $5 \mathrm{mM}$ and chromatin and bound proteins were recovered by centrifugation at $16,100 \mathrm{~g}$ for $30 \mathrm{~min}$ at $4^{\circ} \mathrm{C}$. Pellets were washed once with $0.5 \mathrm{ml}$ binding buffer and resuspended in $10 \mu \mathrm{l} 1 \times$ SDS loading buffer and boiled for $5 \mathrm{~min}$.

Generation of HP1 $\beta$-EGFP mESCs. The mouse HP1 $\beta$ coding sequence was cloned into the pCAGGS-EGFP-IRES-Puro plasmid containing a chicken beta-actin promoter. Stable mHP1 $\beta$-GFP ESC lines were generated by transfecting $6 \mu \mathrm{g} P v u \mathrm{I}-$ linearized vector into mouse WT ESCs.

HP1及 ChIP-seq. For crosslink MNase ChIP of HP1 $\beta, 10^{7}$ TT2 WT mouse ES cells were collected. Cells were crosslinked with $1 \%(\mathrm{v} / \mathrm{v})$ formaldehyde in $10 \mathrm{ml}$ of PBS for $10 \mathrm{~min}$ at RT, then quenched with $0.125 \mathrm{M}$ glycine for $5 \mathrm{~min}$. Cells were washed $1 \times$ with PBS, and resuspended in $1 \mathrm{ml}$ of EZ Nuclei Isolation Buffer (Sigma-Aldrich, Steinheim, Germany). The cytoplasmic supernatant was discarded and the pellet was flash frozen with liquid $\mathrm{N}_{2}$. Nuclei were washed $1 \times$ with MNase wash buffer (50 mM Tris-HCl (pH 8.0), $1.5 \mathrm{mM}$ DTT, $1 \mathrm{mM}$ PMSF, $1 \times$ Protease Inhibitor Cocktail (Roche, Indianapolis, USA)) and resuspended in MNase Digestion Buffer (10 mM Tris- $\mathrm{HCl}$ (pH 7.5), $4 \mathrm{mM} \mathrm{MgCl}_{2}, 1 \mathrm{mM} \mathrm{CaCl} 2,1 \mathrm{mM}$ PMSF, $1 \times$ Protease Inhibitor Cocktail). Chromatin was digested to mono-, di- and tri-nucleosomes with the addition of micrococcal nuclease (NEB, Ipswich, USA) and incubated at $37^{\circ} \mathrm{C}$ for $7 \mathrm{~min}$. Digestion was quenched with the addition of EDTA to a final concentration of $10 \mathrm{mM}$. Cells were then lysed with $1 \mathrm{ml}$ of IP Buffer (0.5\% (v/v) NP-40, 0.1\% (v/v) Sodiumdeoxycholate, $0.1 \%(\mathrm{v} / \mathrm{v})$ SDS, $150 \mathrm{mM} \mathrm{NaCl}, 10 \mathrm{mM}$ EDTA, $1 \mathrm{mM}$ PMSF, $1 \times$ protease inhibitor cocktail) at $4^{\circ} \mathrm{C}$ on a rotator for $1 \mathrm{~h}$. Cell debris was then pelleted, and the soluble chromatin fraction was precleared with Protein A/G Dynabeads (Life Technologies, Carlsbad, USA) at $4^{\circ} \mathrm{C}$, rotating for $2 \mathrm{~h}$. During preclearing, antibody-bead complexes were prepared using antibodies specific for HP1 $\beta$ (clone D2F2, NEB \#8676) and Protein
A/G Dynabeads each, in IP buffer at $4^{\circ} \mathrm{C}$, rotating for $2 \mathrm{~h} .10^{6}$ cell equivalent of chromatin was added to each antibody-bead complex, rotating overnight. Beads were washed and eluted in the presence of RNase A. To reverse cross-linking, eluted DNA was incubated with Proteinase $\mathrm{K}$ and high salt $\mathrm{O} / \mathrm{N}$ at $65^{\circ} \mathrm{C}$. DNA was then purified with phenol:choloroform.

A third of ChIP and input DNA (10-20 ng total) underwent end repair with T4 and Klenow, A-tailing and adaptor ligation. Following ligation, libraries were amplified using primers to the adaptors with eight PCR cycles. Resulting PCR was then purified on 2\% EX Gel (Life Technologies, Carlsbad, USA) at the 200-700 bp range, and quantified on Qubit and Agilent Tapestation.

For ChIP from GFP-HP $1 \beta$ mESC fixation was done using double cross-linking with $\mathrm{Di}(\mathrm{N}$-succinimidyl)-glutarate $(2 \mathrm{mM}$ final concentration) and $1 \%(\mathrm{v} / \mathrm{v})$ formaldehyde ${ }^{63}$. An $\alpha$-EGFP antibody (Invitrogen, A11122, $5 \mu$ g per IP) was used for IP. 10 ng DNA from ChIP sample was used for library preparation. Briefly, end repair, dA tailing and adapter ligation were performed following the NEBNext ChIP-seq Sample Prep Master Mix (New England Biolabs, Ipswich, USA) guidelines and enriched by PCR amplification (18 cycles) before sequencing. $100 \mathrm{bp}$ paired-end sequencing was performed on Illumina Hi-Seq 2000.

Data sets and read processing. Following published data sets were downloaded from NCBI/GEO for this study: SPR899601/ H3K9me3 SETDB1 ${ }^{\mathrm{f} /-}$ and SPR899602/H3K9me3 SETDB1 - / - both done with anti-H3K9me3 antibody $(\mathrm{ab} 8898)^{36}$. Reads were processed and aligned to the mouse reference genome (mm9) using QuasR in R. Genomic alignment was performed twice using BOWTIE with the following parameters: --strata, --best and -m 1 or -m 99 to account for reads that map uniquely or up to 99 times in the mouse genome, respectively ${ }^{64}$. For genome-wide comparisons, only uniquely mapping reads were used. Reads mapping up to 99 times were used for ERV analysis and genome browser visualization.

Genome-wide analysis. The mouse genome was partitioned in $1 \mathrm{~kb}$-sized windows, overlapping by $500 \mathrm{bp}$. The number of mapped reads was counted for each window. $\log _{2}$-fold enrichments were calculated as following $\log _{2}$ $\left(\mathrm{N} \_\right.$reads_IP + psc $)-\log _{2}\left(\mathrm{~N} \_\right.$reads_input + psc $)$. psc is a pseudocount constant of 8 to remove low-coverage noise. To exclude potential biases due to annotation issues, the following genomic windows were discarded from this analysis: windows overlapping with satellite repeats and windows not sufficiently covered in input samples. Finally, $3.46 \times 10^{6} 1 \mathrm{~kb}$-sized windows were used.

ERV-type repeat regions were obtained from www.repeatmasker.org. Cumulative read counts overlapping with ERV elements were calculated per repeat instance. Readcounts were normalized to instance length. $\log _{2}$-fold enrichments were calculated as above. Only instances that contained more than one read in all experiments were used.

Transfection of cells and fluorescence microscopy. U2OS 2-6-3 CLTon cells ${ }^{38}$ were kindly provided by Dr Supriya Prasanth (University of Illinois, IL, USA) and maintained in DMEM (high glucose + GlutaMax) (GIBCO/Invitrogen, Darmstadt, Germany) supplemented with $10 \%$ (v/v) TET system approved fetal bovine serum (Clontech, Saint-Germain-en-Laye, France), $50 \mu^{g_{~ m l}{ }^{-1}}$ hygromycin (Carl Roth, Karlsruhe, Germany) and $200 \mu \mathrm{g} \mathrm{ml}^{-1}$ G418 (Clontech, Saint-Germain-en-Laye, France). For fluorescence microscopy, cells were grown on coverslips in a six-well plate without antibiotics. $500 \mathrm{ng}$ plasmid DNA was transfected using Lipofectamine LTX and Plus reagent (Invitrogen, Darmstadt, Germany). $20 \mathrm{~h}$ post transfection, cells were treated with $1 \mu \mathrm{g} \mathrm{ml}^{-1}$ doxycycline for $24 \mathrm{~h}$ for induction of rtTA expression. Cells were washed twice with PBS and fixed with $3.7 \%(\mathrm{v} / \mathrm{v})$ formaldehyde/PBS for $10 \mathrm{~min}$ at RT. Cells were permeabilized with $0.5 \%(\mathrm{v} / \mathrm{v})$ Triton-X100 (PBS) for $5 \mathrm{~min}$ at RT and incubated with $200 \mathrm{ng} \mathrm{ml}^{-1}$ DAPI (PBS) for 5-10 min. Cells were mounted in Vectashield (Vectorlabs, CA, USA). Images were acquired using a Leica SP 5 confocal microscope with a $63 \times$ oil immersion lens (Leica Mikrosysteme, Wetzlar, Germany). $P$ values (according to Student's $t$-test) were calculated using GraphPad QuickCals (GraphPad, CA, USA).

\section{References}

1. Grewal, S. I. \& Jia, S. Heterochromatin revisited. Nat. Rev. Genet. 8, 35-46 (2007).

2. Maison, C. \& Almouzni, G. HP1 and the dynamics of heterochromatin maintenance. Nat. Rev. Mol. Cell Biol. 5, 296-304 (2004).

3. Hiragami, K. \& Festenstein, R. Heterochromatin protein 1: a pervasive controlling influence. Cell Mol. Life Sci. 62, 2711-2726 (2005).

4. Fodor, B. D., Shukeir, N., Reuter, G. \& Jenuwein, T. Mammalian Su(var) genes in chromatin control. Annu. Rev. Cell Dev. Biol. 26, 471-501 (2010).

5. Ayyanathan, K. et al. Regulated recruitment of HP1 to a euchromatic gene induces mitotically heritable, epigenetic gene silencing: a mammalian cell culture model of gene variegation. Genes Dev. 17, 1855-1869 (2003).

6. Verschure, P. J. et al. In vivo HP1 targeting causes large-scale chromatin condensation and enhanced histone lysine methylation. Mol. Cell. Biol. 25, 4552-4564 (2005). 
7. Jacobs, S. A. \& Khorasanizadeh, S. Structure of HP1 chromodomain bound to a lysine 9-methylated histone H3 tail. Science 295, 2080-2083 (2002).

8. Nielsen, P. R. et al. Structure of the HP1 chromodomain bound to histone H3 methylated at lysine 9. Nature 416, 103-107 (2002).

9. Thiru, A. et al. Structural basis of HP1/PXVXL motif peptide interactions and HP1 localisation to heterochromatin. EMBO J. 23, 489-499 (2004)

10. Hediger, F. \& Gasser, S. M. Heterochromatin protein 1: don't judge the book by its cover! Curr. Opin. Genet. Dev. 16, 143-150 (2006).

11. Mishima, Y. et al. Hinge and chromoshadow of HP1alpha participate in recognition of $\mathrm{K} 9$ methylated histone $\mathrm{H} 3$ in nucleosomes. J. Mol. Biol. 425, 54-70 (2013).

12. Azzaz, A. M. et al. Human heterochromatin protein lalpha promotes nucleosome associations that drive chromatin condensation. J. Biol. Chem. 289, 6850-6861 (2014).

13. Nishibuchi, G. et al. N-terminal phosphorylation of HP1alpha increases its nucleosome-binding specificity. Nucleic Acid Res.. (in the press) 42, 12498-11 (2014).

14. Kilic, S., Bachmann, A. L., Bryan, L. C. \& Fierz, B. Multivalency governs HP1alpha association dynamics with the silent chromatin state. Nat. Commun. 6, 7313 (2015)

15. Aucott, R. et al. HP1-beta is required for development of the cerebral neocortex and neuromuscular junctions. J. Cell Biol. 183, 597-606 (2008).

16. Munari, F., Rezaei-Ghaleh, N., Xiang, S., Fischle, W. \& Zweckstetter, M. Structural plasticity in human heterochromatin protein lbeta. PLOS ONE 8, e60887 (2013)

17. Seeliger, D. et al. Quantitative assessment of protein interaction with methyl-lysine analogues by hybrid computational and experimental approaches. ACS Chem. Biol. 7, 150-154 (2012).

18. Hansen, J. C. Conformational dynamics of the chromatin fibre in solution: determinants, mechanisms, and functions. Annu. Rev. Biophys. Biomol. Struct. 31, 361-392 (2002)

19. Marquart, J. A. SPR Theory and Practice. http://www.lulu.com/spotlight/ amarquart (2013)

20. Fabrini, R. et al. Monomer-dimer equilibrium in glutathione transferases: a critical re-examination. Biochemistry 48, 10473-10482 (2009).

21. Fischle, W. et al. Regulation of HP1-chromatin binding by histone H3 methylation and phosphorylation. Nature 438, 1116-1122 (2005).

22. Mangenot, S., Leforestier, A., Vachette, P., Durand, D. \& Livolant, F. Salt-induced conformation and interaction changes of nucleosome core particles. Biophys. J. 82, 345-356 (2002).

23. Pepenella, S., Murphy, K. J. \& Hayes, J. J. A distinct switch in interactions of the histone $\mathrm{H} 4$ tail domain upon salt-dependent folding of nucleosome arrays. J. Biol. Chem. 289, 27342-27351 (2014).

24. Gordon, F., Luger, K. \& Hansen, J. C. The core histone N-terminal tail domains function independently and additively during salt-dependent oligomerization of nucleosomal arrays. J. Biol. Chem. 280, 33701-33706 (2005).

25. Chin, J. W., Martin, A. B., King, D. S., Wang, L. \& Schultz, P. G. Addition of a photocrosslinking amino acid to the genetic code of Escherichiacoli. Proc. Natl Acad. Sci. USA 99, 11020-11024 (2002).

26. Maison, C. et al. Higher-order structure in pericentric heterochromatin involves a distinct pattern of histone modification and an RNA component. Nat. Genet. 30, 329-334 (2002).

27. Muchardt, C. et al. Coordinated methyl and RNA binding is required for heterochromatin localization of mammalian HP1alpha. EMBO Rep. 3, 975-981 (2002).

28. Meehan, R. R., Kao, C. F. \& Pennings, S. HP1 binding to native chromatin in vitro is determined by the hinge region and not by the chromodomain. EMBO J. 22, 3164-3174 (2003).

29. Canzio, D. et al. Chromodomain-mediated oligomerization of HP1 suggests a nucleosome-bridging mechanism for heterochromatin assembly. Mol. Cell 41, 67-81 (2011)

30. Munari, F. et al. Methylation of lysine 9 in histone $\mathrm{H} 3$ directs alternative modes of highly dynamic interaction of heterochromatin protein hHPlbeta with the nucleosome. J. Biol. Chem. 287, 33756-33765 (2012).

31. Nady, N. et al. Recognition of multivalent histone states associated with heterochromatin by UHRF1 protein. J. Biol. Chem. 286, 24300-24311 (2011).

32. Matsui, T. et al. Proviral silencing in embryonic stem cells requires the histone methyltransferase ESET. Nature 464, 927-931 (2010).

33. Bulut-Karslioglu, A. et al. Suv39h-dependent H3K9me3 marks intact retrotransposons and silences LINE elements in mouse embryonic stem cells. Mol. Cell 55, 277-290 (2014).

34. Karimi, M. M. et al. DNA methylation and SETDB1/H3K9me3 regulate predominantly distinct sets of genes, retroelements, and chimeric transcripts in mESCs. Cell Stem Cell 8, 676-687 (2011).

35. Brind'Amour, J. et al. An ultra-low-input native ChIP-seq protocol for genome-wide profiling of rare cell populations. Nat. Commun. 6, 6033 (2015).
36. Leung, D. et al. Regulation of DNA methylation turnover at LTR retrotransposons and imprinted loci by the histone methyltransferase Setdb1. Proc. Natl Acad. Sci. USA 111, 6690-6695 (2014).

37. Janicki, S. M. et al. From silencing to gene expression: real-time analysis in single cells. Cell 116, 683-698 (2004)

38. Sathyan, K. M., Shen, Z., Tripathi, V., Prasanth, K. V. \& Prasanth, S. G. A BEN-domain-containing protein associates with heterochromatin and represses transcription. J. Cell Sci. 124, 3149-3163 (2011).

39. Cheutin, T., Gorski, S. A., May, K. M., Singh, P. B. \& Misteli, T. In vivo dynamics of Swi6 in yeast: evidence for a stochastic model of heterochromatin. Mol. Cell Biol. 24, 3157-3167 (2004).

40. Cheutin, T. et al. Maintenance of stable heterochromatin domains by dynamic HP1 binding. Science 299, 721-725 (2003).

41. Festenstein, R. et al. Modulation of heterochromatin protein 1 dynamics in primary Mammalian cells. Science 299, 719-721 (2003).

42. LeRoy, G. et al. Heterochromatin protein 1 is extensively decorated with histone code-like post-translational modifications. Mol. Cell. Proteomics 8, 2432-2442 (2009).

43. Canzio, D. et al. A conformational switch in HP1 releases auto-inhibition to drive heterochromatin assembly. Nature 496, 377-381 (2013).

44. Teif, V. B., Kepper, N., Yserentant, K., Wedemann, G. \& Rippe, K. Affinity, stoichiometry and cooperativity of heterochromatin protein 1 (HP1) binding to nucleosomal arrays. J. Phys. Condens. Matter 27, 064110 (2014).

45. Canzio, D., Larson, A. \& Narlikar, G. J. Mechanisms of functional promiscuity by HP1 proteins. Trends Cell Biol. 24, 377-386 (2014).

46. Zentner, G. E. \& Henikoff, S. Regulation of nucleosome dynamics by histone modifications. Nat. Struct. Mol. Biol. 20, 259-266 (2013).

47. Kwon, S. H. \& Workman, J. L. The heterochromatin protein 1 (HP1) family: put away a bias toward HP1. Mol. Cells 26, 217-227 (2008).

48. Kwon, S. H. \& Workman, J. L. The changing faces of HP1: From heterochromatin formation and gene silencing to euchromatic gene expression: HP1 acts as a positive regulator of transcription. Bioessays $\mathbf{3 3}$, 280-289 (2011).

49. Padeken, J. \& Heun, P. Nucleolus and nuclear periphery: velcro for heterochromatin. Curr. Opin. Cell Biol. 28, 54-60 (2014).

50. Towbin, B. D., Gonzalez-Sandoval, A. \& Gasser, S. M. Mechanisms of heterochromatin subnuclear localization. Trends Biochem. Sci. 38, 356-363 (2013).

51. Luger, K., Dechassa, M. L. \& Tremethick, D. J. New insights into nucleosome and chromatin structure: an ordered state or a disordered affair? Nat. Rev. Mol. Cell Biol. 13, 436-447 (2012).

52. Razin, S. V. \& Gavrilov, A. A. Chromatin without the 30-nm fiber: constrained disorder instead of hierarchical folding. Epigenetics 9, 653-657 (2014).

53. Maeshima, K., Imai, R., Tamura, S. \& Nozaki, T. Chromatin as dynamic 10-nm fibers. Chromosoma 123, 225-237 (2014)

54. Ryu, Y. \& Schultz, P. G. Efficient incorporation of unnatural amino acids into proteins in Escherichia coli. Nat. Methods 3, 263-265 (2006).

55. Robinson, P. J., Fairall, L., Huynh, V. A. \& Rhodes, D. EM measurements define the dimensions of the "30-nm" chromatin fiber: evidence for a compact, interdigitated structure. Proc. Natl Acad. Sci. USA 103, 6506-6511 (2006).

56. Luger, K., Rechsteiner, T. J. \& Richmond, T. J. Expression and purification of recombinant histones and nucleosome reconstitution. Methods Mol. Biol. 119, 1-16 (1999).

57. Fischle, W., Franz, H., Jacobs, S. A., Allis, C. D. \& Khorasanizadeh, S. Specificity of the chromodomain Y chromosome family of chromodomains for lysine-methylated ARK(S/T) motifs. J. Biol. Chem. 283, 19626-19635 (2008).

58. Leitner, A. et al. Expanding the chemical cross-linking toolbox by the use of multiple proteases and enrichment by size exclusion chromatography. Mol. Cell Proteomics 11, 014126 (2012).

59. Leitner, A., Walzthoeni, T. \& Aebersold, R. Lysine-specific chemical cross-linking of protein complexes and identification of cross-linking sites using LC-MS/MS and the xQuest/xProphet software pipeline. Nat. Protoc. 9, 120-137 (2014).

60. Christian, H., Hofele, R. V., Urlaub, H. \& Ficner, R. Insights into the activation of the helicase Prp43 by biochemical studies and structural mass spectrometry. Nucleic Acids Res. 42, 1162-1179 (2014).

61. Yang, B. et al. Identification of cross-linked peptides from complex samples. Nat. Methods 9, 904-906 (2012).

62. Herzog, F. et al. Structural probing of a protein phosphatase 2A network by chemical cross-linking and mass spectrometry. Science 337, 1348-1352 (2012).

63. Nowak, D. E., Tian, B. \& Brasier, A. R. Two-step cross-linking method for identification of NF-kappaB gene network by chromatin immunoprecipitation Biotechniques 39, 715-725 (2005).

64. Langmead, B. Aligning short sequencing reads with Bowtie. Curr. Protoc. Bioinformatics Chapter 11, Unit 11.7 (2010). 


\section{Acknowledgements}

We thank Winfried Lendeckel for excellent technical assistance, Uwe Plessmann for help in MS analyses, Adrian Schomburg for analytical ultracentrifugation analysis, Aydan Bulut-Karslioglu for generating the GFP-HP1 $\beta$ mESC cell line and Dr Jun-ichi

Nakayama (Nagoya City University, Japan) for critical reading of the manuscript. Members of the Fischle laboratory provided multiple inputs throughout the study. This work was funded by a predoctoral fellowship of the Boehringer Ingelheim Fonds (S.S.), the German Research Society (DFG, SFB 860 to H.U.) and the Max Planck Society (W.F.). T.B. is supported by the Swiss National Science Foundation (PP00P3_157488).

\section{Author contributions}

K.H.-H., S.S. and W.F. designed the study and analysed data. K.H.-H. and S.S. did biochemical and biophysical analysis of hHP1 $\beta /$ chromatin interaction and effects. S.S. performed SFM studies, while K.H.-H. and S.K. investigated the cellular role of hHP1 $\beta /$ chromatin interaction. M.N., A.C. and H.U. performed and analysed MS data of crosslinks. C.C. and M.L. performed native ChIP-seq experiments. I.A.D. and T.J. performed ChIP-seq studies using tagged HP1 $\beta$. T.B. performed all bioinformatics analyses. H.M.Z. and B.Z. set up and analysed SPR experiments. W.P. and P.J.W. established and analysed FCS measurements. B.W. and H.N. helped with photo cross-linking analysis. N.K. did chromatin-clustering analysis of hHP1 $\beta$ with tailless histones. D.S. made peptides for NCL. K.H.-H and W.F. wrote the manuscript. All authors commented on the final draft.

\section{Additional information}

Accession codes: HP1 $\beta$ ChIP-seq datasets were deposited at the Gene Expression Omnibus (GEO) of National Center for Biotechnology Information under the accession number GSE71114.

Supplementary Information accompanies this paper at http://www.nature.com/ naturecommunications

Competing financial interests: The authors declare no competing financial interests.

Reprints and permission information is available online at http://npg.nature.com/ reprintsandpermissions/

How to cite this article: Hiragami-Hamada, K. et al. Dynamic and flexible H3K9me3 bridging via HP1 $\beta$ dimerization establishes a plastic state of condensed chromatin. Nat. Commun. 7:11310 doi: 10.1038/ncomms11310 (2016).

\section{(c) (i)}

This work is licensed under a Creative Commons Attribution 4.0 International License. The images or other third party material in this article are included in the article's Creative Commons license, unless indicated otherwise in the credit line; if the material is not included under the Creative Commons license, users will need to obtain permission from the license holder to reproduce the material. To view a copy of this license, visit http://creativecommons.org/licenses/by/4.0/ 